\title{
HUMAN RightS AS PART OF CUSTOMARY INTERNATIONAL LAW: A Plea FOR CHANGE OF PARADIGMS*
}

Anthony D'Amato**

\section{THE NEED FOR OBJECTIVE VERIFICATION}

We can all agree that we are experiencing a rather exhilarating elevation of consciousness about human rights throughout the world. The question for us international lawyers is how, and how much of, this public sentiment for human rights has been transformed into binding international law. There is no question that some of it has. Prior to 1945 a government would not be deemed to have violated international law by the mass murder of its own citizens in its own territory. Josef Stalin's purges of the 1930s resulted in the deaths of over twenty million Russian citizens-history's worst genocide. The international community hardly noticed that it was happening. International lawyers of the time believed that what Stalin did was within the sovereignty of the Soviet Union, it was a matter of "domestic jurisdiction," it was "their business."

The legally significant breakthrough events for human rights were the Nuremberg trials following the Second World War (establishing that genocide was a war crime) and the Genocide Convention of $1948^{1}$ (establishing genocide as a crime under international law whether committed in time of war or peace.) These events ripped open the veil of sovereignty, destroying the claim of governments that they were not internationally accountable for what they did to their own citizens in their own territory. Other international law prohibitions upon governmental acts within what was previously "domestic jurisdiction" followed upon the initial breakthrough for genocide.

These other prohibitions include those listed by Louis Henkin, the keynote speaker in the Colloquium of which the present essay is a part: genocide, apartheid ("systematic racial discrimination"), slavery, extra-judicial killing

* Copyright 1994 Anthony D'Amato.

** Leighten Professor of Law, Northwestern University.

${ }^{1}$ Convention of the Prevention and Punishment of the Crime of Genocide, Dec. 9, 1948, 78 U.N.T.S. 277. 
or disappearances, and torture or inhuman treatment. ${ }^{2}$ When the world from time to time learns of egregious instances of these prohibitions hardly anyone disputes the proposition that they violate international law.

It is not difficult for professional international lawyers and scholars to identify the easy, egregious cases. The easy case by definition is uncontroversial. But for every easy case, there are hundreds of peripheral cases that might or might not fall within the broad prohibitions. How should international scholars define the vague norms listed by Professor Henkin in order to present a clearer picture of what kinds of cases they include and what kinds of cases they exclude? Is human abortion, for example, an instance of genocide, as many right-to-lifers claim? What about government funding for abortion-isn't that even closer to genocide because the state is making a decision that potentially millions of abortions will be facilitated and funded? Is capital punishment a form of genocide? Does "mass rape" (as terrible as it is, and as much we may desire it to be included) come within the definition of genocide?

Is indentured labor a form of slavery? Does international law prohibit purchasing the work product of indentured labor? Does a nation violate the anti-slavery norm if it imports goods that were manufactured under conditions that the importer, but not the exporter, might call "indentured servitude"?

What are the parameters of torture? Does it have to be "official torture" to count as a violation of human rights norms, or would torture by paramilitary or irregular troops, or even a band of criminals, also violate the anti-torture norm? Is the battering of wives "torture"? And where can one draw the line between torture and inhumane treatment or punishment? Professor Henkin lists freedom from "torture or other inhuman treatment or punishment" as a universal human right. ${ }^{3}$ For him, at least, there is no need to draw a line between torture and inhuman treatment or punishment; both are prohibited. But, then, what constitutes "inhuman treatment or punishment"?

I can think of numerous practices in the United States today that many thinking people would include within the ambit of that phrase. Capital punishment, barred in many countries but not in the United States, could be one prominent example of inhuman punishment. Placing a prisoner in

${ }^{2}$ Louis Henkin, Human Rights and State “Sovereignty", 25 GA. J. INT'L \& COMP. L. 31, 37 (1995-96) (citing the RESTATEMENT, infra note 6) [hereinafter Henkin].

${ }^{3}$ Id. at 37. 
solitary confinement-depriving the prisoner of human society-is another. A great deal of the inhuman treatment that occurs in prisons in the United States is done deliberately but indirectly-prison guards "looking the other way" as a new inmate is forcibly raped and sodimized by the other prisoners. What about the widespread sale by prison guards of crack, cocaine, and heroin to prisoners, creating "junkies" even of inmates who had not engaged in substance abuse before being imprisoned? What about the provision in the most recent federal crime bill of "three strikes and you're out"-creating the possibility of indefinitely long prison sentences even for minor crimes so long as a person has committed three of them? These and many other "features" of the American criminal justice system surely can be, and have been, characterized by thoughtful persons as cruel and inhuman. All of these are problems of specification. We need to know more than just the words genocide, slavery, torture, inhuman treatment or punishment. There is no point arguing over what the proper definitions of these words might be, because we're talking about the international-law definitions and not Webster's (nor Henkin's, nor our) definitions.

Thus, we have an important definitional problem. It implies a second, related problem: where do the definitions come from? We can call this second problem the source problem. We need to solve the definitional and source problems at the same time. We need to determine an objective source for the human rights we're talking about, and then we need to consult the source for definitions.

We cannot be content with just a list of human rights of the sort that Professor Henkin gives in his keynote address. There are many other rights that some people allege to be human rights under international law. What about, for example, a human right against capital punishment? Or a human right against arbitrary detention (think of Haitian boat people)? Or a right of freedom of movement within one's country (a right denied to women in several Islamic countries)? Or the right to freedom of expression (think about Salmon Rushdie and the "crime" of blasphemy)? We need an objectively verifiable international-law source for all human rights if we want to show that any particular right is part of international law.

Although international scholars in their own studies must show a grounding of any claimed international legal norms in an objectively verifiable source, the need is even more important with respect to outsiders. Although international scholars may not need much convincing that at least Professor Henkin's core list of human rights are part of international law, some may have the uneasy feeling that Professor Henkin is preaching to the 
converted. What about skeptical lawyers who are not international lawyers-don't they have every right to ask us to prove that human rights are part of international law binding upon all states? Even some international lawyers, such as Professor Weisburd, a contributor to the present Symposium, justifiably question whether we have shown where our human rights norms come from and whether they can be objectively proven to be part of international law. ${ }^{4}$

The first and most convenient place to look for an account of the sources of human rights law is Professor Henkin's keynote address. Given his renown in the field of international law, it is and must be an authoritative statement of the prevailing view of the place of human rights in international law. ${ }^{5}$ Additionally, Professor Henkin invokes throughout his paper the authority of the Restatement (Third) of the Foreign Relations Law of the United States. ${ }^{6}$ The Restatement, in turn, derives much of its authority from the author of the passages cited, Louis Henkin.

I will proceed to argue that Professor Henkin's view of the internationallaw source of human rights stems from a paradigm that governs his account; I will call it the Sovereignty Paradigm. From within the world-view represented by this paradigm, Professor Henkin's keynote address deals with the question whether human rights are part of international law and, if so, how we know it. I will argue that so long as one remains within the Sovereignty Paradigm, the answers that issue forth will be incoherent. The Sovereignty Paradigm must be overthrown because it makes no sense.

I do not intend to criticize Professor Henkin's personal views, nor does my critique stem from the classic orneriness of a student departing from his teacher's cherished beliefs. On the contrary, I focus upon Professor Henkin's interpretation because it is the prevailing paradigm on our subject and because he has stated it so well. Paradigms are notoriously resistant to attack; to change them one must effect a change in the entire "world view" of their proponents." As Thomas Kuhn has demonstrated, paradigms grip our imagination and are nearly impossible to dislodge. In Kuhn's account of the history of science, established scientists hardly ever shed their

4 Arthur M. Weisburd, The Effect on the Customary Law of Human Rights of Treaties and other Formal International Acts, 25 GA. J. INT'L \& COMP. L. 99 (1995-96).

${ }^{3}$ See generally Henkin, supra note 2, at 31 .

6 RESTATEMENT (THIRD) OF THE FOREIGN RELATIONS LAW OF THE UNITED STATES (1987) [hereinafter RESTATEMENT].

7 Thomas KuHN, The Structure of Scientific Revolutions 110 (1962). 
paradigms; rather, it takes a new generation of scientists, whose minds are not prisoners of the old paradigm, to effectuate its replacement.

Accordingly, the task I face may be hopeless. Perhaps only young readers are open to my arguments. I certainly have failed to persuade Professor Henkin over the years, even though he has been familiar with the alternative point of view that I have been in the process of developing ever since 1962, the year he agreed to supervise my doctoral dissertation. Since then I have published aspects of this alternative view, but not all in one place or comprehensively. The present essay is my first attempt to confront head-on the school of thought that Professor Henkin's essay represents. I would not even have attempted it at the present time if Richard Lillich had not invited me to participate in this Colloquium and then, with his characteristic gentleness, insisted.

\section{THE SOVEREIGNTY PARADIGM}

\section{A. The Sources of Human Rights According to Professor Henkin}

\section{1. "Non-Conventional Law"}

The generally accepted view of international scholars is that there are only two sources of international law: customary and conventional. Of these, custom is the only universal source, generating law that is binding on all nations (including new nations). Conventions simply create law directly for their signatories (I postpone to the end of this essay the complication that conventions can also be a source of custom). Other misnamed "sources," such as the decisions of international and national courts and the writings of publicists, at best are interpretive; they do not directly create law. ${ }^{8}$

${ }^{8}$ See Karl Doehring, The Participation of International and National Courts in the LawCreating Process, 17 S. AFR. Y.B. INT'L L. 1 (1991-92), excerpted in INTERNATIONAL LAW ANTHOLOGY 102 (Anthony D'Amato ed., 1994) [hereinafter INT'L LAW ANTHOLOCY]; Louis Sohn, Equity in International Law, 82 PROC. AM. SOC'Y INT'L L. 277 (1988), excerpted in INT'L LAW ANTHOLOGY at 102; Anthony D'Amato, What Does It Mean to Be an Internationalist?, 10 MICH. J. INT'L L. 102 (1989), excerpted in INT'L LAW ANTHOLOGY at 103; Anthony D' Amato, What Counts as Law?, in LAWMAKING IN THE GLOBAL COMMUNTTY 83 (Nicholas G. Onuf ed., 1982), excerpted in INT'L LAW ANTHOLOGY at 104. For a brief discussion of "general principles," at best a distillation of prevailing jurisprudential attitudes towards law, and not a "source" of 1 law, see HERSCH LAUTERPACHT, 1 INTERNATIONAL LAW 69-70 (1970), excerpted in INT'L LAW ANTHOLOGY at 101-02. 
Resolutions of the United Nations are not a source of law at all; if they were, the United Nations would be a world legislature. At best, those resolutions help interpret the prescriptions contained in the U.N. Charter.'

Acknowledging the classic view that customary law and conventions are the two principal sources of international law, ${ }^{10}$ Professor Henkin rules out conventions as a source of human rights law. If treaties were the source of human rights norms, then under Professor Henkin's view of treaties they would only bind the states that signed them (he does not subscribe to the view that treaties can be a source of custom). The result, in his view of the matter, would deprive human rights law of its universality-a universality not only insisted upon by Professor Henkin, but evident from the fact that no state has made the claim that it, or its regional group, is exempt from certain basic human rights norms such as the laws prohibiting apartheid, genocide, slavery, and torture.

By ruling out conventions, Professor Henkin is left with custom. Custom is, traditionally at least, the only source of international law that yields universal norms. However, Professor Henkin denies that human rights norms have their origin in custom. Indeed, Professor Henkin asserts that the emerging law of human rights "is not based on 'custom,' [is not based] on state practice at all." 11

Having ruled out both customary and conventional law, Professor Henkin resolves his dilemma of finding a source for human rights norms by inventing a new source: "non-conventional" law. ${ }^{12}$ It reminds me of a bright but difficult child predicting that she will not draw the red ball from a bag that contains one red ball and one blue ball, reaching in and drawing out one ball, and then announcing that the ball in her hand is not blue. If she is asked whether she means that the ball is red she replies, "I didn't say it was red. All I said is that it was not blue." Perhaps she has invented a

9 Stephen M. Schwebel, The Effect of Resolutions of the U.N. General Assembly on Customary International Law, 73 PROC. AM. SOC'Y INT'L L. 301 (1979), excerpted in INT'L LAW ANTHOLOGY, supra note 8, at 105; Stephen M. Schwebel \& Anthony D'Amato, Contemporary Views on the Sources of International Law: The Effect of U.N. Resoulations on Emerging Legal Norms, 73 PROC. AM. SOC'Y INT'L L. 300 (1979), excerpted in INT'L LAW ANTHOLOGY, supra note 8, at 106; Anthony D'Amato, Israel's Air Strike Upon the Iraqi Nuclear Reactor, 77 AM. J. INT'L L. 584 (1983), excerpted and adapted in INT'L LAW ANTHOLOGY, supra note 8, at 107.

${ }^{10}$ Henkin, supra note 2, at 37.

11 Id. at 38.

${ }^{12}$ Id. at 37. 
wholly new category, non-blue, but we suspect that her term is simply a circumlocution for "red." If it is not, she would be obliged to tell us something about this new category-where it comes from, what it does, how we can recognize it when we see it, how it is justified. If she refuses to explain, we shrug our shoulders and simply conclude that she is creating an unnecessary difficulty with her choice of language. Similarly, when Professor Henkin tells us that (a) human rights are universal, (b) they are not conventional, (c) they are not customary, and (d) they are "non-conventional", his "explanation" is suspect.

Of course, if Professor Henkin can endow his new source with recognizable features, then perhaps it is just a code word for those features. Accordingly, he tells us that "non-conventional law" is itself derived from "liberal national constitutions" and from "jus cogens." Let us examine these contentions.

\section{Liberal National Constitutions as a Source}

The primary new source of human rights law, Professor Henkin tells us, is based on "contemporary national sources."13 It derives "from national constitutional rights" found in "liberal national constitutions." 14 The most basic rights include, in the order in which Professor Henkin mentions them, the outlawry of apartheid, of genocide, of slavery, of extra-judicial killing or disappearances, and of torture or inhuman treatment.

Suppose a fair-minded neutral observer accepts Professor Henkin's statements, but wishes to check for herself the derivation and content of his list of basic rights. What national constitutions should she consult? If she were to examine every constitution in the world, she would find that a majority of them do not provide for these (or other) human rights. What then? Should she conclude from the non-mention of these rights that they are not part of international law? Or should she simply exclude the majority of constitutions (that don't mention these rights) on the ground that they are not "liberal"? Recall that Professor Henkin used the phrase "liberal national constitutions." Perhaps Professor Henkin so qualified his new source to avoid the majority-rule problem. Even so, how can the researcher test constitutions for liberalism? Are "liberal" constitutions to be defined as only those which are liberal enough to list the human rights that Professor Henkin

\footnotetext{
${ }^{13}$ Id. at 40.

${ }^{14}$ Id. at 40.
} 
is looking for?

Perhaps we can figure out what "liberal national constitutions" Professor Henkin has in mind by looking at the examples he gives. In a footnote, he mentions the constitutions of the United States and France. ${ }^{15}$ But where, in those constitutions, does he find a prohibition against apartheid? Or against genocide? Or against extra-judicial killing or disappearance? Or against torture or inhuman treatment? These are the most prominent rights in Professor Henkin's own list of human rights. Even the right against slavery was not to be found in the original United States Constitution; it took a civil war and a set of post-civil war amendments to outlaw slavery. Most constitutions today do not explicitly outlaw slavery, probably because, unlike pre-civil war United States, they did not have a prior history of it. Most constitutions likewise do not mention genocide or extra-judicial killing or disappearances or torture or inhuman treatment. If Professor Henkin's chief source for human rights law is national constitutions (liberal or otherwise), why do hardly any of those constitutions mention the human rights on his list? Is it really credible to claim that human rights law as we know it today derives from national constitutions? Or even from the sub-category of liberal national constitutions? Or even from the sub-sub-category of the constitutions of the United States and France?

If Professor Henkin were to argue that all the human rights on his list are derivable, in the case of the United States Constitution, from the Due Process Clause (an argument that on its face is plausible), wouldn't that prove too much? Surely international law does not incorporate all the constitutional decisions explicating the Due Process Clause, all the nuances of American civil and criminal procedure associated with that clause, the long and complex historical explication of "substantive due process," and all the other paraphernalia associated with that umbrella clause in American constitutional law. And if international law did include all these things, does it also include all the explications and nuances of clauses similar to the Due Process Clause found in other national constitutions?

If Professor Henkin in fact cannot locate the human rights on his list in "liberal national constitutions," could he argue that they would be in those constitutions if those constitutions were appropriately amended to include them? This would of course be a gigantic bootstrap argument. But, if we for the moment concede the bootstrap, we still are not told how we get from constitutional law to international law. National constitutions are simply a

${ }^{15}$ Id. at 40 n.34. 
source of national law and not a source of international law. ${ }^{16}$ If that were not true, foreign constitutions could be cited by American litigants in American courts as overruling contrary principles in the United States Constitution. Consider, for example, the two national issues debated in the United States Congress in 1994: gun control and health care. Does Professor Henkin believe that if a considerable number of liberal national constitutions in the world today provided for gun control, such a provision would spring into international law and serve to override the Second Amendment to the United States Constitution? Or if a majority of foreign constitutions provided for universal health care for their citizens, would Professor Henkin say that there would be no need for a health-care debate in the Congress of the United States because Americans would automatically be entitled to health care as a matter of international law? Surely one cannot persuasively claim that what other countries provide in their national constitutions affect the rights of non-nationals under international law. If such a claim were true, then any nation could change international law simply by amending its own constitution. If brief, national constitutions simply are not, and have never been, sources of international law. It is rather astounding that Professor Henkin wants to elevate them to the status of sources of international law in order to "explain" what he means by "nonconventional" law.

Perhaps it can be argued on behalf of Professor Henkin that he is only talking about deriving the idea of human rights, and not the international law of human rights, from national constitutions. His essay perhaps should be read as a contemporaneous account of the sentiment of human rights and not the law of human rights. Indeed, if we were to go through his essay and substitute the word "sentiment" each time we see the word "law," some of his contentions would become persuasive. We would learn that the sentiment of human rights is on the increase throughout the world, that it is harder and harder for governments to oppose that sentiment, and that more and more people think that human rights are good things. But his essay takes a wrong turn when he attributes this sentiment of human rights to "liberal national constitutions." Such a thesis, as confined just to the sentiment of human rights (not to mention the law of human rights), vastly understates the readily available evidence. A careful study of the history of the idea of human rights by Burns Weston lists numerous fundamental sources of the idea of

${ }^{16}$ See HANS Kelsen, PRINCIPLES OF INTERNATIONAL LAW 406 (1952), and infra note 27. 
human rights, only a minor one of which is national constitutions. ${ }^{17}$ It would appear that Professor Henkin, who is surely aware of the history recounted by Professor Weston, has settled on national constitutions (instead of the intellectual history of the past thirty centuries) as the source for the international law of human rights because he would like his readers to believe that he is talking about law and not about sentiment. There appears to be something "legal" about national constitutions that is missing from other documents such as the doctrines of the Greek stoics, the essays of the Philosophes, the writings of John Locke and John Stuart Mill, and all the other sources cited by Professor Weston. It would not do to argue that human rights are part of international law because John Locke or John Milton or John Stuart Mill said so. But, it might do (if readers aren't paying close attention) to say that human rights are part of international law because it is so provided in liberal national constitutions. A constitution is a "law" and international law is "law" so maybe no one will notice that it takes sleight-of-hand to move from one to the other.

What Professor Henkin has done is to invent a new source of international law-namely, provisions in liberal national constitutions-to explain where human rights law comes from. But since national constitutions are not a source of international law, invoking them is hardly explanatory of the content of international law. His "explanation" is far more controversial than the thing explained. Our desire to know where human rights law comes from is hardly satisfied by the assertion that it is derived from "liberal national constitutions" when those constitutions themselves are clearly not a source of international law.

\section{Jus Cogens as a Source}

Professor Henkin offers a second "source" for human rights law:

Conceptually, it [human rights law] may have sneaked into the law [international law] on the back of another idea, "ius cogens." 18

${ }^{17}$ Bums H. Weston, Human Rights, ENCYCLOPEDIA BRTTANICA, excerpted in INT'L LAW ANTHOLOGY, supra note 8, at 21.

${ }^{18}$ Henkin, supra note 2, at 38. Throughout his essay, Professor Henkin places key terms in quotation marks, such as "non-conventional" law and "jus cogens," "custom," and "intervention." Since he is not quoting anyone, the use of quotation marks appears to be a 
Despite the fact that jus cogens performed this difficult feat so stealthily that no one other than Professor Henkin seems to have noticed it, the fundamental objection to Professor Henkin's theory is that jus cogens is itself, at best, a meta-norm and not a source of norms. ${ }^{19}$ I say "at best" advisedly, because in fact no one knows where jus cogens comes from, no one knows whether or how or why it is part of international law, no one knows its content, no one knows how to modify it once it is articulated, and indeed no one knows whether it even exists (although it is certainly talked about a lot)..$^{20}$ The strangeness of Professor Henkin's "non-conventional law" source of human rights is not "explained" by invoking the even stranger notion of jus cogens. It's almost like saying that the source of Hurricane Edna now ravaging New Jersey was a computer error by a meteorologist on Channel Seven. ${ }^{21}$

\section{B. The Arbitrariness of Professor Henkin's "Sources"}

From time immemorial, rules of law have been recognized as being capable of objective identification and verification. The opposing parties in any case or controversy have, in principle, equal opportunity to read the same materials and to argue the content of the law to a judge or tribunal. The judge, in turn, has the opportunity of looking up the sources to doublecheck counsel. If the plaintiff's attorney claims that $\mathrm{X}$ is the applicable rule of law in the case, she will either cite a statute (or other regulation) in the jurisdiction, or argue that $\mathrm{X}$ represents the best "fit" in the most closely analogous case law. She will cite the cases she relies upon, so that her opponent may read the same cases and have the opportunity to deny that $\mathrm{X}$ is the rule of decision in those cases. Her opponent may also bring up other cases and other statutes, which she in turn will have the opportunity to read.

stylistic device designed to sneer at the terms quoted, as if to say that he does not take all this stuff seriously and neither should we.

19 Vienna Convention on the Law of Treaties, arts. 53, 64, opened for signature May 23, 1969, 1155 U.N.T.S. 331.

${ }^{20}$ See Anthony D'Amato, It's a Bird, It's a Plane, It's Jus Cogens!, 6 CoNN. J. INT'L L. 1 (1990), excerpted in INT'L LAW ANTHOLOGY, supra note 8, at 116. Article 64 of the Vienna Convention on the Law of Treaties says a peremptory norm (jus cogens) can be superseded by a norm of the same character, but the Convention does not inform us where the superseding norm comes from.

${ }^{21}$ Leading to the irresistible follow-up: the hurricane caused twenty million dollars worth of improvements. 
The court will then consider the statutes and cases cited by the parties in deciding whether $\mathrm{X}$ is the applicable rule of law in the case. The "law," in short, is something objective. Only objectively verifiable law has any chance of guiding a judge (or other decision-maker) away from arbitrary decisionmaking. ${ }^{22}$

But when we consider Professor Henkin's keynote address, we find no basis for objectively determining and verifying any of the human rights on his list. Although we might agree with the items he chose, the list itself is arbitrary. We cannot know for sure, on the basis of the "sources" Professor Henkin has given, whether any particular right belongs on the list. We cannot know why Professor Henkin included some rights and excluded others. The arbitrariness of his approach may be evidenced by the fact that he has recently changed his mind about the most important human right on his list. In his contribution to a book published five years ago, he attacked humanitarian intervention on the ground that "the use of force remains itself a most serious - the most serious-violation of human rights." ${ }^{23}$ But today, that "most serious" violation of human rights is conspicuously absent from his list.

Not only is it absent, but in fact Professor Henkin now seems to approve of the use of force. In his keynote address he approves of the fact that the "international system . . . has sometimes encouraged states to 'intervene' in other states in support of human rights."24 Of course, Professor Henkin is entitled to change his mind..$^{25}$ He was entitled to argue in 1989 that forcible intervention was the most serious violation of human rights, and entitled also to so thoroughly change his mind in 1994 that the same violation does not even make his list. But if Professor Henkin changes his mind, that's something quite different from the entire international legal system changing its mind. It is clear that if $\mathrm{X}$ was the "most serious" human rights violation five years ago, the world hasn't changed so much that today $\mathrm{X}$ doesn't even make a list of principal human rights violations. We simply cannot imagine the nations of the world undergoing such a radical change

22 I've hedged this sentence to reflect a lengthy exposition of the matter. See Anthony D'Amato, Pragmatic Indeterminacy, 85 Nw. U. L. REV. 148 (1990).

${ }^{23}$ Louis Henkin, The Use of Force: Law and U.S. Policy, in RIGHT V. MIGHT: INTERNATIONAL LAW AND THE USE OF FORCE 37, 61 (Council on Foreign Relations 1989).

24 Henkin, supra note 2, at 33.

${ }^{25}$ I might fantasize that a book review I wrote had something to do with his change of mind. See Anthony D'Amato, Review of Might v. Right, 85 AM. J. INT'L L. 201 (1991) (book review). 
in just five years. Instead, the only logical conclusions are either that Professor Henkin was right in 1989 and is wrong in 1994, or was wrong in 1989 and is right today, or that his "source," like tea leaves that only he can interpret, yields whatever norms he likes.

I believe Professor Henkin has undermined his own cause by his talk about "non-conventional" law. I am sure that he is sincerely, even passionately, committed to the proposition that the human rights on his list are part of universally binding international law. He believes in the primacy of the individual. He believes that people have basic rights and that these rights can be asserted against states. He believes that national and international courts can and should enforce these rights as a matter of law. Yet by failing to provide those courts with any objectively determinable basis for identifying and verifying as part of international law any of the rights on his list, Professor Henkin has ended up debasing the very rights he wants to elevate above all norms.

Yet the story is not quite complete by alleging that Professor Henkin has "failed" to provide us with a source for human rights in international law. It is not simply that he has failed; the problem goes a lot deeper. Within his world view, he cannot provide us with a source for human rights law. As I shall now proceed to argue, the Sovereignty Paradigm that rules his thinking disables him from providing a determinable and verifiable source.

\section{The Sovereignty Concept in International Law}

Professor Henkin rightly spent the opening part of his keynote address on the subject of sovereignty. It is the key to the question of "where he is coming from." In order to locate his Sovereignty Paradigm within the various versions of sovereignty in international law, let us consider six permutations of "sovereignty," the sixth of which I will call the Sovereignty Paradigm:

1. The most extreme version of sovereignty could be called strict national sovereignty. In this view, nations are sovereign over international law. Therefore, international law exists only to the extent that each nation decides to obey it. Even if a nation has decided to obey a rule of international law, it may change its mind at any time, and if it changes its mind, the rule loses its force against that nation.

This strict view of sovereignty is simply a cumbersome way of saying that international law is not "law." It is not "law" because nations are entitled (by virtue of the sovereignty theory) to disobey it at will. For the person 
who believes that international law is really $1 \mathrm{aw},{ }^{26}$ strict national sovereignty makes no sense.

2. A sibling of the strict sovereignty view is the theory known as Dualism. Dualists believe that international law and national law are two separate, independent legal orders, each valid in its own sphere. National law governs the "internal" or "domestic" affairs of a state, while international law governs its "foreign" affairs. ${ }^{27}$

If dualism were a correct theory of international law, internal affairs would be fixed for all time as purely internal. Anything within a state's domestic jurisdiction would have to remain within a state's domestic jurisdiction, forever impervious to international legal regulation. For under the dualist theory, both international law and domestic law would be powerless to transform domestic subject-matter into international subject-matter; neither of these legal regimes has any "jurisdiction" over the other. But if we all accept the fact that genocide moved from a purely internal matter prior to 1939 to an international matter after 1945, then dualism cannot describe the new status of the prohibition against genocide. Prior to 1939 , what a government did to its own citizens within its own territory-including mass murder-was purely within its internal law, its "domestic jurisdiction." If dualism were a correct theory then nothing that transpired since 1939 could

${ }^{26}$ See Anthony D'Amato, Is International Law Really "Law"?, 79 Nw. U. L. REV. 1293 (1984), excerpted in INT'L LAW ANTHOLOGY, supra note 8, at 37.

${ }^{27}$ Consider Hans Kelsen's classic critique of dualism:

Every so-called domestic affair of a state can be made the subject matter of an international agreement and so be transformed into a foreign affair .... If we discard the spatial metaphor, we thus find that the attempted distinction between the subject matters of national and international law is mere tautology. The so-called "domestic affairs" of a state are, by definition, those which are regulated by the national law: the "foreign affairs" are, by definition, those which are regulated by international law. The assertion that national law regulates domestic affairs, and international law foreign affairs, boils down to the truism that national law regulates what is regulated by national law, international law what is regulated by international law.

Still there remains a certain truth in the statement that international law is "interstate" law, whereas national law is, so to speak, one-state law. But, as pointed out, this differentiation does not concern the subject matter; it concerns the creation of international and national law. Whereas national law is created by acts of one state alone, . . . international law is usually created by the cooperation of two or several states.

KELSEN, supra note 16, at 405-06. 
transform domestic mass murder into an international crime. Since we now routinely say that a government is prohibited by international law from committing genocide against its own citizens within its own territory, we must discard the theory of dualism. ${ }^{28}$

3. Dualism, as we have seen, involves a division of subject matter between the internal and the international. A variant on dualism involves a division of the two main sources of international law. Advocates of this position, such as Grigori Tunkin or Phillip Trimble, say that treaties are binding on signatory states, but customary law is only binding to the extent that any state wishes to recognize it. ${ }^{29}$

The variant on dualism is subject to the same objection as the preceding one: that the division is artificial, and crumbles over time. For example, states negotiate treaties against a customary law background. They know when a provision deviates from the customary rule, and the extent of the deviation figures into the negotiation process. Moreover, states know that the words in the treaty incorporate customary-law meanings that have evolved over centuries, and if they wish to depart from the standard meaning, they must make it explicit in the treaty. Thus, it would be artificial and distorting in the extreme to interpret treaties as if the customary-law context did not exist. Yet dualists, by disavowing customary law, are forced into arguing that each state party to a treaty must apply its own internal law to the interpretation of the treaty. Resort to the separate legal systems of the parties for interpretation of a common document is a recipe for aggravating, not solving, international disputes. ${ }^{30}$ More importantly, it misunderstands the way international courts and international organizations deal with questions of treaty interpretation.

${ }^{28}$ Additionally, as we will see below, dualism would be unable to account for the rise of many rules of customary international law that even dualists today concede are part of international law, such as the rule that a state may not deny justice to an alien within its territory.

${ }^{29}$ See generally, DEBATE: The "Domestication" of Intermational Law, in INT'L LAw ANTHOLOGY, supra note 8, at 400-10.

${ }^{30}$ See, e.g., United States v. Alvarez-Machain, 112 S. Ct. 2188 (1992). By ignoring international customary law, the majority opinion reached a result that was counterproductive and costly for the international interests that the court's majority thought it was acting to preserve. See Jacques MacChesney \& Anthony D'Amato, Facts of the Alvarez Case, INT'L LAW ANTHOLOGY, supra note 8, at 246; Malvina Halberstam \& Anthony D'Amato, DEBATE: Abduction Does Not Violate the U.S.-Mexico Extradition Treaty, INT'L LAW ANTHOLOGY, supra note 8 , at $248-54$. 
Also applicable here is the objection I made above about genocide. Under the "treaty only" variant of dualism, any nation today is free under international law to commit genocide against its own population within its own territory unless it has ratified the Genocide Convention. So, the United States was free to commit genocide prior to 1989 , the year it belatedly ratified the Genocide Convention. If these propositions strike you as outrageous, then you should reject the "treaty-only" variant of dualism.

4. A different notion of sovereignty is that some states, but not all, are sovereign over international law. One variant on this view is that some states have greater law-creating power than other states. Among the few people who have asserted this position are Charles DeVisscher, who said that the major powers carry more weight in the formation of international custom, ${ }^{31}$ and Myres McDougal who said that General Assembly resolutions are binding if accepted by the major powers. ${ }^{32}$

This position has been thoroughly discredited on the ground not only that it contradicts the rule of equality of states under international law, but also because it neither offers any persuasive reason to the minor powers why they should obey the rules of international law nor explains why they do obey it. $^{33}$

5. A related view is that some states have sovereignty over international law in the sense that they are exempt from some or all of its rules. This position has been taken by the Ayatollah Khomeni and by Professor McDougal, both invoking a higher morality which when followed allows a nation to depart from international rules that are binding on other nations. Khomeni derives his binding moral precepts from Allah; McDougal derives his from Harold Lasswell. ${ }^{34}$

${ }^{31}$ Charles DeVisscher, Theory and Reality in Public International Law 149 (P.E. Corbett trans., 2d ed. 1968).

${ }^{32}$ Myres McDougal, Remarks at the Panel on Contemporary Views on the Sources of International Law, 73 AM. SOC'Y INT'L L. PROC. 327-32 (1979).

${ }^{33}$ Of course, in practice, some states succeed in playing a bigger role in the formation of international law than other states. Not every state exerts itself to the same extent. See generally ANTHONY D'AMATO, THE CONCEPT OF CUSTOM IN INTERNATIONAL LAW 64-66 (1971).

${ }^{34}$ In his famous essay on hydrogen bomb testing, Professor McDougal argued that the United States would not, but the Soviet Union would, be violating international law by engaging in such testing, on the ground that only the United States, as between the two superpowers, exemplifies the Lasswellian free-world virtues. For the position of Professors McDougal and Schlei and my critique of it, see DEBATE: Custom As Reasonableness, INT'L 
This variant is subject to the same objections as the previous one. It contradicts the rule of equality of states which is the foundation of international law. And, if some states are "above" international law, why should the states who are "below" it obey it?

Incidentally, I do not think that the curious notion of the "persistent objector" is an instance of any of these variants on sovereignty. Supporters of the "persistent objector" thesis (which include Professor Henkin ${ }^{35}$ ) do not claim that any particular state is above international law. They only claim that any state which meets certain criteria for the status of persistent objector is able to carve out an exception for itself from the particular rule of customary law to which it has persistently objected. ${ }^{36}$

6. We arrive finally at the Sovereignty Paradigm. ${ }^{37}$ It has the following characteristics, according to Professor Henkin:

-that the state system is committed exclusively to state values, principally to state autonomy and the impermeability of state territory, and to the welfare of the state as a monolithic entity;

-that international law is based on the consent of states, and is made only by states and only for states;

- that the international system and international law do not

LAW ANTHOLOGY, supra note 8, at 89-94.

${ }^{35}$ See Henkin, supra note 2, at 38, 44.

${ }^{36}$ See The Persistent Objector: DEBATE, INT'L LAW ANTHOLOGY, supra note 8, at 110 15 (excerpting Jonathon I. Chamey, The Persistant Objector Rule and the Development of Customary International Law, 56 BRT. Y.B. INT'L L. 1 (1986) and Ted L. Stein, The Approach of the Diffrent Drummer: The Principle of the Persistent Objector in International Law, 26 HARV. INT'L L.J. 457 (1985)). My own view is that a state cannot exempt itself from a customary rule in formation by announcing that it will not be bound by it, any more than I can announce that I will not be bound by new case law in an emerging field of law in the United States on the ground that I was not one of the parties to the case and I object to the court's decision.

${ }^{37}$ The Sovereignty Paradigm as characterized by Professor Henkin has sometimes been referred to as "domestic jurisdiction." See, e.g., Anthony D'Amato, Domestic Jurisdiction, ENCYCLOPEDIA OF INTERNATIONAL LAW 1090-96 (Rudolf Bernhardt ed. 1992). The term "domestic jurisdiction" could be logically harmless, meaning essentially, that everything not controlled by international law is reserved to the domestic jurisdiction of each state. But psychologically, those who invoke the term mean more than that. They look upon international law as an invader of domestic jurisdiction, as an unwelcome foreign influence. Domestic jurisdiction is primary; intemational legal obligations are secondary. 
(may not) address what goes on within a state; in particular, how a state treats its own inhabitants is no one else's business, not the business of the system, not the business of any other state;

- that a state may concern itself with what goes on inside another state only as that impinges on its own state interests. (Therefore, a state may presume to afford "diplomatic protection" to its diplomats or its nationals, not to other human beings. $)^{38}$

Of course, on the level of strict logic, the idea of human rights is incompatible with the Sovereignty Paradigm. Human rights are universal rights; they are rights against every nation in the world including one's own nation. Professor Henkin is well aware of this logical incompatibility. He argues that human rights norms have made inroads upon the Sovereignty Paradigm. He states that human rights have become "international law" through a process of radical derogation from the traditional sovereign prerogatives of states. ${ }^{39}$ His is a sort of Swiss Cheese view of sovereignty: there's plenty of cheese, but there are holes in it (for human rights).

Unlike the other five variants on sovereignty, the Sovereignty Paradigm is rooted in psychology. It is closest in form to the second of the variants I discussed above (dualism), but rather than insisting that internal affairs are impervious to international law, it takes the position that internal affairs are strongly presumed to be a matter for the individual nation and that this presumption may only be rebutted by a powerful showing that a particular norm of international law has penetrated the domestic-jurisdiction barrier. The Sovereignty Paradigm is important because psychology can be more powerful than logic.

In the above quotation from Professor Henkin's address, note the use of the key term "derogation." Human rights, in his view, are derogations

${ }^{38}$ Henkin, supra note 2, at 32. In addition, Professor Henkin lists two other "assumptions." Id.

39 Id. at 32-33.

${ }^{10} \mathrm{He}$ again uses it later in his address: "In recent years, international concern for human rights has led to even more 'intrusive enforcement,' more stringent derogations from sovereignty.' "Id. at 43 . The pervasive use of quotation marks around key terms in Professor Henkin's essay seems to be used as a device to cast some doubt on the very language he employs, as I suggested above, supra note 18, or to undercut his own constructs, or to present a fuzzy picture to the reader. This may be evidence of Professor Henkin's lack 
from sovereignty. (It's as if we really don't want holes in our Swiss Cheese, but we put up with them.) Anyone familiar with the development of the common law understands the psychological power of the concept of derogation. From the eleventh century to the seventeenth, the English common law courts regarded acts of Parliament as derogations from the common law. From a strictly logical, as opposed to psychological, point of view, it wouldn't matter whether statutes are derogations from common law or common law is a derogation from statutory law. But psychologically, the courts' idea that statutes are derogations from common law led them to construe statutes "strictly"-to grudgingly allow statutes to control a case if the statutory language was clear and the case clearly fell within its terms, but otherwise to decide the case on common-law grounds. Statutes were given very little breathing room. Indeed, in many cases courts found some way or other to construe a statute so that it did not strictly apply to the case at hand, and then proceeded to ignore the statute.

This attitude persisted into the eighteenth century when finally Jeremy Bentham turned the situation around by coming up with a replacement paradigm. Bentham contended that statutes were the primary sources of law (law is a "command" of the sovereign), and that they should be broadly construed so as to control as many cases as possible. Bentham's Positivist Paradigm succeeded in replacing the reigning Common Law Paradigm. The resulting interchange of power between parliament and judiciary was immense, and has persisted to the present day.

Professor Henkin and others who are immersed in the Sovereignty Paradigm will grudgingly allow some human rights norms to creep under the sovereignty tent. The norms are admitted as "exceptions" to sovereignty, as "derogations" from sovereignty. As with all derogations from a norm, the burden of proof falls upon human rights. Even though as a matter of personal preference Professor Henkin might like to see an increasing acceptance of human rights in international law, the very foundation he stands upon presents a psychological barrier against the spread and penetration of those rights. ${ }^{41}$

of conviction in his own essay. It may indicate, in short, that he realizes that the "source" he is invoking makes no logical sense and that the "sovereignty" he clings to is an atavism.

${ }^{41}$ His basic view seems akin to the way I once described the nineteenth century view that a state might have of its own jurisdiction: "Everything that goes on within our borders is our business and international law only applies to those times when we bump up against other units. We bump up against them on the high seas or when there's a war or at a few other 
Because I am talking about psychological attitudes here, permit me a personal observation: nearly all American international lawyers I know who once served in the Office of the Legal Adviser of the Department of State, or on the legal staff of the Pentagon, or in the Foreign Service, seem to be among the strongest adherents to the Sovereignty Paradigm. Somehow, governmental service seems to convince American lawyers, day after day, to become suspicious of, if not hostile to, "international law" as a sneaky attempt by pipsqueak nations to bulldoze the United States into doing something contrary to our policy or national interest. This kind of hubris, I think, comes from an exalted sense of personal power derived from working for the most powerful government on earth.

In the foreign offices of lesser powers, lawyers might attain the perspective that Georges Scelle called "dedoublement fonctionnel"-by making claims and alternatively passing on the claims of others, one develops an international perspective. But maybe this largeness of attitude noticed by Scelle only works when one's nation needs international law as much as it fears it.

In the United States, at least so far, there is a prevalent feeling among our governmental officials and the lawyers who work in government departments such as the Pentagon and the State Department that international law is only a tool to be used in the national interest, and not something that we should allow to give any advantage in any case to a militarily inferior nation. Our governmental and ex-governmental lawyers fear international law more than they use it; they fear its use by other nations against us, and they don't use it too much themselves because they have other ways-withholding aid, using economic muscle, threatening the use of force-to get what they want. I do not claim that all governmental and ex-governmental lawyers have this attitude or display it all of the time, nor that they don't from time to time take positions totally contrary to prevailing United States policy. I am only saying that they seem intellectually to come from within the Sovereignty Paradigm, and that it colors everything they think about international law, including the international law of human rights.

We must assume that Professor Henkin is well aware of the Sovereignty Paradigm within which he works and that he knows it places a psychological barrier against human rights. Despite a keynote address that impassionately

times. But our boundaries carve out a certain territory that's our own and doesn't affect other territories." Anthony D'Amato, A Seminar on Custom, INT'L LAW ANTHOLOGY, supra note 8, at 74. 
welcomes the arrival of human rights law, he appears to have an even stronger conviction that international norms of human rights should not be binding as law upon the United States. His closing words reveal his true position:

We, too, have to accept international standards, the expression of the contemporary moral intuition, when they are higher than ours, e.g., to outlaw capital punishment for juvenile crimes, or to protect against inhuman or degrading treatment. We have to pay a decent respect to the opinions of mankind by submitting to international scrutiny (e.g., by the Human Rights Committee, pursuant to the Protocol), to the International Court of Justice, to the Inter-American Court of Human Rights. We, too, exercising our sovereignty, must consent to be governed and help achieve good international governance for living in a decent world. ${ }^{42}$

When Professor Henkin says "we have to," he means "we ought to." He is not saying that we are compelled by law, he is saying that we ought to choose to accept external norms. We must "consent to be governed," he says in his last sentence, emphasizing the fact that unless we consent we are not, in his view, governed by these international norms. In short, as much as Professor Henkin himself may deplore capital punishment for juvenile offenders, for example, he is unwilling to concede to the international community any legal power to make that prohibition effective within the United States. Psychologically, he is still a dualist; international law cannot tell the United States government what to do internally, unless the government consents to particular norms. (Thus, it would have been perfectly legal under international law for the United States government to have committed genocide prior to 1989 , if I correctly interpret what Professor Henkin is really saying.)

Professor Henkin's keynote address is an exercise in sociology, not law. Clinging to the Sovereignty Paradigm, he describes the world's increasing receptivity toward human rights and adjures the United States to consent to a longer list of norms, but can never bring himself to say that the norms-except for a few generally stated and uncontroversial ones such as those involving genocide, apartheid, slavery, and torture-are legally binding

${ }^{42}$ Henkin, supra note 2 , at 45. 
on the United States. In the final reckoning, Professor Henkin chooses sovereignty over human rights. As much as he believes in the cause of human rights, he believes even more in the right of the United States to decide its own policies without interference from international norms that have developed outside the United States. Like many of the present Justices of the Supreme Court, Professor Henkin will not allow foreign nations to lay down the law for us. No matter how strong the human rights norm against capital punishment of juveniles may develop in foreign nations, the adherents to the Sovereignty Paradigm do not want to constrain the right of states within the United States or the federal government to execute juveniles convicted of certain crimes. Nor are they in a position to "make an exception" for a norm like the one against capital punishment of juveniles: they are afraid of opening a wedge for future norms that they might not like, and in any event they lack a coherent theoretical basis for determining the content of international human rights. This unwillingness to open the U.S. door to foreign norms may be why Professor Henkin lists only the safest, vaguest, and most uncontroversial norms as having attained international-law status.

To be sure, if Professor Henkin's address together with all his previous writings show that sovereignty is more important to him than human rights, he is entitled to his preference, but we are also entitled to "know where he is coming from." We are entitled, that is, to take his denunciation of the "shibboleth of 'sovereignty" "43 with a grain of salt, knowing that to Professor Henkin sovereignty turns out to be much more than a shibboleth. We are entitled to take his assertion that "an occasional state cannot veto law that reflects the contemporary international political-moral intuition" ${ }^{\prime 4}$ as still leaving an escape hatch for the United States when a norm arises that the United States doesn't like: either because the United States is not a mere "occasional state" in Professor Henkin's view, or because, if the crunch comes, Professor Henkin will be available to announce that the unwanted norm does not reflect the contemporary international "political-moral intuition." In short, his statement is a recipe for auto-interpretation of human rights norms.

The Sovereignty Paradigm, like all the other variants on the theme of sovereignty, is foundationally incompatible with the idea of human rights. In a major recent development, thirty-seven states participating in the

${ }^{43} I d$. at 43.
${ }^{4} I d$. at 44. 
Conference on Security and Co-operation in Europe explicitly recognized this incompatibility, and charted in the Moscow Document a new approach to human rights:

The participating States emphasize that issues relating to human rights, fundamental freedoms, democracy and the rule of law are of international concern, as respect for these rights and freedoms constitutes one of the foundations of the international order. They categorically and irrevocable declare that the commitments undertaken in the field of the human dimension of the Conference on Security and Participation in Europe are matters of direct and legitimate concern to all participating States and do not belong exclusively to the internal affairs of the States concerned. ${ }^{45}$

Those who cling to the Sovereignty Paradigm while urging the incorporation of human rights into international law are somewhat like the tobacco company executive who offers to lead an anti-smoking campaign. We have every right to wonder whether the executive is leading the campaign because: (a) it gives him some degree of control over it, (b) the campaign will take place regardless of whether he leads it, and (c) if someone not connected to the tobacco industry winds up leading the campaign it might turn out to be a resounding success. Similarly, when a leading international scholar whom we have every reason to believe is utterly sincere in his dedication to human rights is "coming from" the Sovereignty Paradigm, we have good reason to doubt either the underpinnings of his apparent dedication, or, at least, the effectiveness of his presentation.

45 Conference on Security and Co-operation in Europe: Document of the Moscow Meeting on the Human Dimension, Moscow, Oct. 3, 1991, reprinted in 30 I.L.M. 160, 1672 (1992) [hereinafter Moscow Document]. The participating states are Albania, Austria, Belgium, Bulgaria, Canada, Cyprus, the Czech and Slovak Federal Republic, Denmark, Estonia, Finland, France, Germany, Greece, the Holy See, Hungary, Iceland, Ireland, Italy, Latvia, Liechtenstein, Lithuania, Luxembourg, Malta, Monaco, the Netherlands, Norway, Poland, Portugal, Romania, San Marino, Spain, Sweden, Switzerland, Turkey, the USSR, the United Kingdom, the United States of America, and Yugoslavia. 


\section{TOWARD A NeUtral Paradigm}

\section{A. Retaining States as Subjects of International Law}

There is a rejoinder that Professor Henkin could make at this point in my essay, should he wish to make it. He would be entitled to say that his attitude toward human rights is and should be irrelevant to his scholarly opinion about the sources of international law. If he concludes on the basis of scholarly research that the source of human rights law is "non-conventional" (whatever that means), that it is not based on the practice of states (whatever that seems to say), and that it is a derogation from sovereignty (even if he says sovereignty is a shibboleth), he is entitled to call these things as he sees them. He is right in resisting any temptation to change his analysis of the sources of human rights law simply because he desires to promote the cause of human rights.

Naturally I would agree with this rejoinder if Professor Henkin wished to make it. I concede that it is possible for people to believe simultaneously in the Sovereignty Paradigm and in the international law of human rights, and if they do, their cognitive dissonance is a private problem for them, having nothing to do with the objective soundness of either the Sovereignty Paradigm or the international law of human rights taken separately. As much as I would personally like to see people resolve this inner contradiction by deciding either that their Sovereignty Paradigm prevents them from full espousal of the cause of human rights in international law (and then refrain from leading the human rights parade), or that their eagerness to see human rights expand to the limits of its logic requires them to discard the Sovereignty Paradigm like a child who eventually grows up and discards a security blanket, they have every right to accept both principles simultaneously and live with the ensuing cognitive dissonance. Paradigms are well-nigh impossible to dislodge from one's mind. But everyone else is entitled to avoid cognitive dissonance if they are not wedded to the Sovereignty Paradigm and would accept the possibility of a replacement paradigm.

I want to suggest a replacement paradigm, bearing in mind Professor Henkin's admonition that "[1]aw professors are a conservative lot. We teach what we were taught, and what we have long taught."46 Just suggesting a replacement paradigm for the Sovereignty Paradigm obviously will not change the minds of conservative legal scholars. Perhaps strategic consider-

${ }^{46}$ Henkin, supra note 2, at 43. 
ation should play a role in choosing a replacement paradigm. There are two replacements that I have considered: a Neutral Paradigm and a Human Rights Paradigm. If I were to follow the tactical lead of that immensely successful publicist Jeremy Bentham, I would opt for a Human Rights Paradigm. Bentham knew how to shake up the conservative legal establishment. Faced with a prevailing paradigm that amounted essentially to a dictatorship of the common law, he replaced it with a paradigm that amounted to a dictatorship of statutory law. By going from one extreme to the other, he made his point more effectively than if he had gone only halfway. By choosing the extreme of a Positivist Paradigm, he was more effective in the real world than if he had chosen a Neutral Paradigm (one that regarded the common law and statutory law on equal terms. $)^{47}$

In the Benthamite tradition, a radical Human Rights Paradigm, as a corrective to the Sovereignty Paradigm, would take the world-view that only persons, and not nations, count in international law. Nations are simply aggregates of persons, but they are not "entities" entitled to separate consideration. $^{48}$ Perhaps adherents of this viewpoint should relabel international law "interpersonal law." In their favor is a long and sorry history of reification of national entities: the bloody wars of nationalism in the nineteenth century (reviving today in Yugoslavia and parts of Africa), the deification of the State in Hegelian philosophy (laying a theoretical foundation for Hitler's Germany and the ensuing world war and holocaust), and the general degradation of the individual as nothing more than a servant of the state.

Even though the Human Rights Paradigm would be an example of Benthamite strategy, I leave it to someone else to advocate it. My view of today's world convinces me that states are here to stay; they are not about to become subordinated to individuals. We may see in the near future a gradual movement toward world federalism on the current European model, but even if there is such a movement, states as components in a federal system will retain many of their competencies. The government of a world federalism will most likely be a government of limited powers. International

${ }^{17}$ Although Bentham may have made the right strategic choice, his Positivist Paradigm has always seemed to me to be an impoverished view of law, despite the efforts of Hans Kelsen and H.L.A. Hart to keep it alive. For my criticisms, see ANTHONY D'AMATO, JURISPRUDENCE: A DESCRIPTIVE AND NORMATTVE ANALYSIS OP THE LAW (1984).

${ }^{48}$ See FERNANDO TESON, HuMANITARIAN INTERVENTION: AN INQUIRY INTO LAW AND MORALITY (1988). 
law as we know it would still have a huge role to play within a world federalism.

But more important than any prediction about these matters is a theoretical reason that for me supports the role of states as subjects of international law at least for the foreseeable future: A state is more than a single representative of the totality of individuals within it; a state embodies the relations among those individuals ${ }^{49}$ as well as all their relations to the territory they inhabit. Moreover, a state embodies the relations of persons living at the moment to their ancestors and to their future offspring. A state, therefore, captures a vast and intricate web of personal and territorial relationships extending into the past and into the future. ${ }^{50} \mathrm{~A}$ state is therefore a different and rather special kind of "player" in the international system. If we dispensed (theoretically) with international law and replaced it with interpersonal law, many of the important relational values embodied in the state would be lost. ${ }^{52}$

49 If one were to add up all the relations between all the individuals in the state, the resulting number would be staggeringly higher than the population total.

so Elsewhere I have called the state a "translucent" entity, to distinguish it from transparent (the equivalent of a Human Rights Paradigm) or opaque (the equivalent of a Sovereignty Paradigm). See Anthony D'Amato, The Relation of the Individual to the State in the Era of Human Rights, 24 TEX. INT'L L.J. 1 (1989), excerpted in INT'L LAW ANTHOLOGY, supra note 8 , at 168.

51 Mathematicians will recognize a parallel here to set theory: the totality of relations among members of a set creates a set of a higher order.

32 Vattel put it this way:

The universal society of the human race being an institution of nature herself, that is to say, a necessary consequence of the nature of man,- -all men in whatever stations they are placed, are bound to cultivate it, and to discharge its duties. They cannot liberate themselves from the obligation by any convention, by any private association. When, therefore, they unite in civil society for the purpose of forming a separate state or nation, they may indeed enter into particular engagements towards those with whom they associate themselves; but they remain still bound to the performance of their duties towards the rest of mankind. All the difference consists in this, that having agreed to act in common, and having resigned their rights and submitted their will to the body of the society, in every thing that concerns their common welfare, it thenceforward belongs to that body, that state, and its rulers, to fulfil [sic] the duties of humanity towards strangers in every thing that no longer depends on the liberty of individuals; and it is the state more particularly that is to perform those duties towards other states. 
I suggest, therefore, that the Sovereignty Paradigm be replaced with a Neutral Paradigm, one that accepts both persons and states as subjects of international law without creating a presumption against either persons or states. In contrast to the Sovereignty Paradigm which represents a psychological barrier against the emergence and spread of human rights norms, the Neutral Paradigm would neither resist nor encourage those norms. Human rights norms would emerge in the international legal system law the same way any other norms emerge. They would have no special status, but they would also have no inferior status.

But, if human rights norms are like any other norms, we face a big conceptual hurdle. Traditional norms of international law (for example, norms relating to the law of the sea, or norms of diplomatic immunity, or the laws of war, or any other traditional subject-matter of international law), arise through the workings of custom. If the Neutral Paradigm calls for treating emerging human rights norms on the same footing as traditional norms, then an explanation is needed for the emergence of human rights norms via the practice of states. The Sovereignty Paradigm as described by Professor Henkin specifically denies that human-rights norms arise through the practice of states.

To recapitulate the argument:

(1) Custom is the only universal international law (my view).

(2) Human rights do not derive from custom (Professor Henkin's view).

(3) At least some human rights norms are part of universal international law (Professor Henkin and I share this view.)

(4) Therefore, one of the above propositions is false. Either (1) is false, and human rights have somehow been established as a wholly new and different form of universal international law (this is Professor Henkin's position-he calls it "non-conventional law"), or (2) is false (this is the position I want to defend).

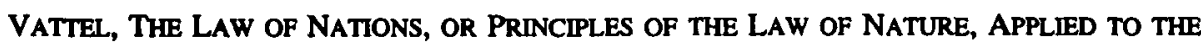
ConduCt AND AFrairs of NATIONS AND SOVEREIGNS, Intro., $\$ 11$, at lx-lxi (Chitty trans. 1852). 


\section{B. The Problem of State Practice}

A paradigm actually tells us what we see in the real world. ${ }^{53}$ Thomas Kuhn gives numerous examples, among which is the fact that Western astronomers, who were gripped by the Ptolemaic paradigm that the stars in the immutable heavens were fixed in place, first saw change in the motion of stars in the half-century after Copernicus' new paradigm was proposed. In contrast, "the Chinese, whose cosmological beliefs did not preclude celestial change, had recorded the appearance of many new stars in the heavens at a much earlier date." 54 When experiments are performed that conflict with the reigning paradigm in a field of science, the experimental result is either deemed an anomaly or is shrugged off as "measurement error." Eventually, if the anomalies pile up, there is a crisis in the field which is resolvable only by the substitution of an entirely new paradigm. Even then, the scientists who in their formative years absorbed the reigning paradigm, used it in their published research and taught it to their students, are likely in most cases to resist the new paradigm and to maintain their own view for their lifetime.

I suggest that the Sovereignty Paradigm does not allow its adherents to see certain aspects of the practice of states. They are blind to the rise of human rights norms in customary law because it does not fit their paradigm. When Professor Henkin asserts that the emerging law of human rights "is not based on 'custom,' is not based on state practice at all," based on what he actually sees. He cannot see the state practice in question because he clings to a paradigm that won't allow him to see it.

In order to see the state practice that is hidden from the view of adherents to the Sovereignty Paradigm, we need to look at the two major components of state practice. The first is the interest and concern of the reacting state in the act committed by the acting state. The second is the interaction of the reacting and the acting states. I am talking about any act at all-whether it falls within the category of human rights, or mining initiatives on the ocean floor, or setting up an embargo, or emitting pollutants into the international environment. For any of these acts to be "noticed" by the international legal

${ }^{33}$ Einstein said (somewhere) that one only sees what one's theory allows one to see. If a scientist is blind to evidence that contradicts her theory, it is because she only sees what she wants to see.

54 KURN, supra note 7, at 115.

${ }^{55}$ Henkin, supra note 2, at 38. 
community and begin to form part of the state practice that leads to customary law, they must be within the interest and concern of the reacting state and they must then form part of an interaction between the reacting state and the acting state. Accordingly, Part IV of this essay deals with the first component: the interest and concern of the reacting (affected) state. Then, in Part V, I take up the issue of interaction leading to custom.

\section{WHY HUMAN RIGHTS NORMS GET STARTED}

As we have seen, the Sovereignty Paradigm adopts a presumption that reserves to a state an ill-defined bundle of internal competencies. The Paradigm is willing to allow international law to arise from a state's interactions with other states (the clearest example is war), because at least those interactions involve more than one state and hence any assertion of "sovereignty" by either state would lead nowhere. On the other hand, when a state acts entirely internally - that is, where no other state is "present" and there is no "interaction" between states-then the Sovereignty Paradigm creates an almost conclusive presumption against the intrusion of any rule of international law. Indeed, by acting internally, there is no "state practice" visible to international law (state practice requires an interaction of two or more states).

With these elaborations, it is clear that Professor Henkin views what a government does to its own citizens within its own territory as an internal act out of which customary law cannot arise. That presents for him a fundamental dilemma, because the law of human rights that he champions must apply to what a government does to its own citizens within its own territory-if it didn't, it would hardly be a human right. Professor Henkin concedes that the international prohibitions of genocide, slavery, and torture apply to acts of any government against any citizen, including acts of a citizen's own government against that citizen. I have tried to show earlier that Professor Henkin's resolution of this dilemma-inventing a strange source called "nonconventional law" or invoking the equally mysterious notion of "jus cogens"-is no resolution at all. What remains is simply an anomaly. From within the Sovereignty Paradigm no coherent explanation of human rights norms in international law is possible.

I will now try to show that the Sovereignty Paradigm cannot explain that which Professor Henkin takes for granted. Consider why a state cannot do whatever it wants to any person within its territory. Why can it not maltreat, 
and deny justice to, an alien within its territory? According to Professor Henkin:

Under customary international law, a state is obligated to treat foreign nationals in accordance with an international standard of justice, and is responsible to the state of the person's nationality for any violations of that standard. ${ }^{56}$

Contrast this accurate statement of customary international law with what a state can do to its own nationals. Stalin's purge of the 1930s was not considered a violation of international law. On the other hand, if Stalin's government at the same time had maltreated or denied justice to a single foreigner in the Soviet Union, that person's government might have demanded immediate redress through diplomatic circles, and newspapers might have reported the maltreatment and atrocity.

Let us consider carefully why it is that a nation under traditional customary law cannot deny justice to an alien within its territory, whereas prior to 1939 it could do whatever it wanted to a national within its territory. A human being is a human being; why was there such a disparity under international law between a human being who is a national and a human being who is an alien?

The disparity obviously did not arise by accident. It was the result of what nations wanted international law to be in the years and centuries prior to 1939. The prerequisite for the formation of any rule of international law, whether customary or conventional, is a state's interest and concern in an act or transaction. After all, international law is nothing but an invention of states that serves their collective self-interest.

Several centuries ago, the interest of a nation in the plight of one of its citizens travelling in a foreign country could be expressed by the phrase "he is one of us." His fellow countrymen had empathy for his plight in a foreign land because they could relate to him. This sense of "belonging" is summed up in the term "national." His fellow citizens cared about him when he travelled abroad. This care translated into the interest and concern of the home nation in the welfare of one of its nationals who was being maltreated by a foreign government in a foreign land. Let me be clear that in saying this much, I have not yet taken up the question of how this interest and concern helps to give rise to a rule of international law. The second step in

${ }^{56}$ Id. at 40 n.32. 
the equation-namely, the interaction of the home state and the foreign state-remains to be shown. Here, I am only saying that if we start with a human being who finds himself in a foreign country and finds himself the victim of a denial of justice by the government of that country, then that person's fellow "nationals" in the home country might have expressed interest and concern for his well-being.

Now I want to show that, as a result of the human rights revolution, our interest and concern for fellow human beings have transcended national boundaries. We now care about the plight of persons in foreign countries even if they are not our "nationals." I am not saying that we necessarily care as much about their welfare as we might care about the welfare of our own nationals in foreign countries, but we do seem to care to the extent of threats to their basic human rights.

Why is any nation in the world today concerned with the human rights of foreigners in foreign countries? What has changed since Stalin's purges of the 1930s? Professor Henkin has provided us with a number of reasons for the human rights revolution, though he has omitted what I believe are the two most important. The first involves concern. It is the result of the power of television to create a bond of empathy about the plight of individuals in far-away lands. David Hume in 1740 wrote about the consequences to morality of the "sympathy" felt by one person when she sees another person suffering and in pain. It is a human and instinctive reaction for the observer to feel a little of that pain and suffering herself. The observer's feeling is not exactly real, it is sympathetic (today we would call this "empathy"). Television has blanketed the world with live pictures of people suffering, starving, and dying in foreign places. These pictures bring home to the viewer a very deep empathetic reaction. The aggregate power of this empathy in the population is translated into government levels (governmental officials themselves are not entirely immune to the same empathy when they watch television), with the result that a state decides that it indeed is concerned with the plight of foreigners in foreign countries. The television phenomenon has changed everyone's view of the world and has convinced people everywhere that they have been, are, and should be concerned about what happens to other people in other countries.

The second reason for the human rights revolution has to do with interest. It is economic interest-the growth and spread of free markets. There is no doubt that, with the end of the Cold War, Karl Marx is figuratively dead and Adam Smith is thriving. The internal dynamic of free markets is their tendency to spread to more and more countries and people. (It was Lenin, 
and not Smith or Marx, who noticed this dynamic in his analysis of capitalist imperialism.) Free trade makes everyone better off by increasing the variety of available goods and lowering their price (increasing the purchasing power of the consumer). ${ }^{57}$ The advantages of external free trade in turn promote today's relentless drive in every country in the world toward internal free trade, that is, private ownership of productive assets, trade among capital producers, negotiations with workers-atomistic individuals engaging in the transactions of capital markets. The "sovereign" in this picture (I use the word apologetically) is the consumer. Advertising is pitched to the consumer; alternatives are presented to the consumer; the consumer is wooed by all these competing businesses. Thus, both the atomism of capital markets and the concept of "the consumer is king" result in an overwhelming demand for personal freedom. It has become increasingly difficult for any government to shackle its citizens, to deny them the autonomy that they are enjoying in the economic sphere. In the face of this world-wide capitalist explosion, governments have responded by "downsizing"-selling off the means of production to their own citizens and to outside investors. Governments are taking an increasingly passive role as facilitators of business initiatives. As I argued in an article written in 1979 when the Cold War was still very much with us, "there is a fundamental affinity between the goals of multinational business enterprise and the goals of human rights." This affinity works both ways. It not only says that capitalist enterprise is good for human rights, but also that human rights are good for capitalist enterprise. Among numerous examples, the recent NAFTA debates in the United States illustrate this point. Despite the rhetoric of labor-union leaders that free trade with Mexico would result in the loss of jobs for American workers, ${ }^{59}$ those workers supported the pact because of deepseated realization that their own standard of living, li.eir own purchasing power, will increase if more goods and services are generated more inexpensively in foreign countries like Mexico. Another way of looking at this is to note that Japan's current huge trade surplus means that many people want, are willing to pay for, and have enjoyed the electronic and automotive products that Japan has produced. Young people who used to

57 See Paul Romer, New Goods, Old Theory and the Welfare Cost of Trade Restrictions, J. DEVEL. ECON. (1994).

58 Anthony D'Amato, Are Human Rights Good for International Business?, 1 Nw. J. INT'L L. \& BUS. 22, 32 (1979).

${ }^{9}$ More likely, the labor-union leaders feared a loss of their own jobs and perks. 
carry big loud radios around the streets ("ghetto blasters") are today noiselessly plugged in to Sony Walkpersons and are enjoying a higher fidelity (and higher volume) at a cheaper price than ever before. In short, we have a present interest and concern in the economic freedom of foreign persons in foreign countries, and this economic freedom supports and is supported by political freedom..$^{60}$

Our economic interest and empathetic concern for the human rights of foreigners in foreign countries is now a psychological fact of human existence. It directly runs up against the psychology of the Sovereignty Paradigm. According to the latter, what goes on in a foreign country between the government and its "own" people in its own territory is none of our business. The human rights revolution, aided by the growth of television and the spread of free markets, tells us on a daily basis that what goes on in a foreign country is our business, and more so with the passage of time. We are much more concerned with the internal affairs of our "trading partners" (soon the whole world) than we were in the 1930s with what went on in the Soviet Union-a time when international trade was minimal and where the brutality of the purges were invisible to a nonexistent CNN television network.

If centuries ago nations developed an interest and concern in the welfare of their "nationals" when under the jurisdiction of foreign governments, we need a word today to describe a similar interest and concern in the welfare of "foreigners" when under the jurisdiction of foreign governments. Over a decade ago I suggested the word "international" for this relationship. ${ }^{61}$

${ }^{6}$ See, e.g., Thomas L. Friedman, A Peace Deal Today Really Is a Bargain, N.Y. TIMES, Sept. 11, 1994, \& 4, at 1. Mr. Friedman notes:

[P]eace has unexpectedly broken out in the Middle East, South Africa and even Northern Ireland in the last 12 months. . . .

There is no way an increasingly bourgeois Israeli society could read every day about the phenomenal growth rates in Singapore or Thailand without asking themselves: 'What are we doing wasting our time putting up caravan homes ... in the West Bank?' There was an intuitive understanding that a gravy train was passing them by.

'Global markets reward good economic performance and punish bad economic performance more quickly than ever.'

${ }^{61}$ Anthony D'Amato, The Concept of Human Rights in International Law, 82 COLUM. L. REV, 1110 (1982):

[I]f $A$, a national of state $X$, is tortured by State $X$, State $Y$ has an international-law [sic] entitlement against $X . \ldots A$, as it turns out, is an "international" of State $Y$ just as he is a "national" of State $X$. 
Thus, I can claim to be a "national" of the United States and "international" of every other country. Thus, we care about our "internationals" starving in Burundi or dying in a brutal civil war in Bosnia. Although our concern for our "nationals" may be deeper and cover a wider array of rights, we also care about the plight of our "internationals" in other countries. At the present time we haven't developed our sensitivities to the point where we care as much if foreign citizens are denied justice by their own governments as we care if one of our citizens is denied justice by that same foreign government. But this is just another way of saying that international human rights are, at present writing, less inclusive than the constitutional rights enjoyed by citizens in several countries. As an American "national" I have certain constitutional rights that may be more extensive than my rights as an "international." Yet in some venues it may turn out that my "international" rights are more valuable than my "national" rights. (And, for some people in some countries, their "international" rights may be more extensive than the rights they have under their home country's constitution.) In any event, the fact that both the "national" and "international" set of rights may overlap does not present a conceptual problem.

Whether or not we use the cumbersome term "our internationals" or not, breaking free of the Sovereignty Paradigm requires giving up the notion that what one's own government does to one's own nationals is no other country's business. Perhaps most people in the world today have overcome whatever Sovereignty Paradigm they might have internalized sixty years ago. Perhaps the only people who still seriously cling to it are law professors. Of these law professors, one of the most prominent, who by virtue of his commitment to human rights has the least reason to cling to it, is Professor Henkin.

In short, the true meaning of the human rights revolution that Professor Henkin talks about is a rising interest and concern about the rights of foreigners in foreign countries. It is as if people all over the world are coming to a sense of global consciousness that their own rights are better secured in a world where everyone enjoys those rights. We have internationalized our interest and concern, and thus have taken the first necessary step toward the formation of an international customary law of human rights.

Id. at 1147. The word "international" is a bit cumbersome, and probably won't catch on. But I think it remains useful for analytical purposes. 


\section{HOW HUMAN RightS NORMS GET STARTED}

\section{A. "State Practice"}

In the previous section, under the rubric of a Neutral Paradigm that does not presume against either people or states, I tried to show that states have an increasingly developing interest and concern in what happens to foreigners in foreign states. But that interest and concern, while it may suffice to combat the psychological barrier raised by the Sovereignty Paradigm, does not in itself amount to customary international law. A second step is needed, namely, the interaction of two or more states, because the mere fact that state $M$ cares about what happens to people in state $N$ is not enough to create customary law. Unless there is some interaction between $M$ and $N$, M's interest and concern simply means that $M$ (at best) desires that there should be an international norm regulating N's conduct. That desire does not translate into customary law unless there is an element of state practice. The term "state practice" means an interaction of two or more states on the international level. That interaction must be provable; there must be evidence of state practice.

We recall that Professor Henkin said that human rights norms are "not based on ... state practice at all."62 Yet elsewhere in his paper he conceded that "[u]nder customary international law, a state is obligated to treat foreign nationals in accordance with an international standard of justice. ..."63

Professor Henkin has made two assertions: (1) the obligation to treat foreign nationals in accordance with an international standard of just is a rule of customary international law, and (2) customary international law is based on state practice. Both assertions are undoubtedly correct. Yet under Professor Henkin's Sovereignty Paradigm, we can now ask how assertion (1) could ever have arisen. Where is the state practice that Professor Henkin rightfully insists upon in order for a rule of custom to arise? I want to argue that Professor Henkin cannot consistently maintain both that human rights norms are not based on state practice and that the obligation to treat foreign nationals in accordance with an international standard of justice is based on state practice. I want to show that his assertions (1) and (2) logically compel him to abandon his claim that human rights norms are not based on state

\footnotetext{
${ }^{62}$ Henkin, supra note 2, at 38 .

${ }^{63}$ Id. at 40 n.32.
} 
practice. But I am not just interested in uncovering a logical inconsistency in Professor Henkin's views; I want to show generally that, as a positive matter, human rights norms are as much based on state practice as classical norms such as the obligation to treat foreign nationals in accordance with an international standard of justice.

\section{B. A Thought Experiment}

The historical records are scant, so I would like to proceed on the basis of a thought experiment. Let us imagine a case of first impression, one that could have arisen a century or two prior to the writings of Vattel (who acknowledged that a state had an international obligation not to deny justice towards aliens in its territory). Imagine that a person $\mathbf{P}$, living and residing in country $C$, travels to country $D$. While minding his own business walking down a street in $D$, he is suddenly arrested. He is taken to the police station, beaten, and thrown into prison. He is not charged with any violation of D's laws. P's relatives and friends back in $C$ obtain the support of officials of government $\mathbf{C}$ to bring diplomatic pressure upon officials of government $D$. Assume that C's diplomatic protest is the first time a country ever lodged a protest regarding maltreatment of its national.

For the very reason that this is a case of first impression, the prior "law" on the subject must have been in favor of $D .{ }^{64}$ What this means is as follows: a person $\mathrm{P}$, from any country (say, C) would, upon entering upon the territory of another country (say, D) become fully subject to the jurisdiction of D just like any other person within D. P's outside nationality, that is his C-nationality, would be irrelevant once $P$ is physically present in D. By entering into the territory of $D, P$ has subjected himself to D's sovereign power. $D$ can do whatever it wants to do, to any of its own nationals within $D$ as well as to any visitors present within $D$, such as $P$. Since this is well before the era of human rights, there is no legal limit whatsoever on what the government of $\mathrm{D}$ can do to any person within $\mathrm{D}$.

However, under our hypothetical, $C$ has issued a protest on behalf of $P$. $\mathrm{C}$ contends that $\mathrm{D}$ has some obligations toward $\mathrm{P}$. The degree of $\mathrm{D}$ 's

${ }^{64}$ In my view, the idea that there are "gaps" in the law is incoherent. The law is a binary system. In any case, either the plaintiff wins or the plaintiff loses. If there is no "legal matter" the plaintiff can cite to that would win for the plaintiff, then the plaintiff loses. The lack of "legal matter" is simply another way of saying that, under the law, the defendant wins. See Anthony D'Amato, Legal Uncertainty, 71 CAL. L. REV. 1 (1983). 
obligations toward P can be located somewhere between D's obligations toward its own nationals, which is a zero degree of obligation (from an international law standpoint in the pre-human rights era), and D's obligations toward C's ambassadors who are physically present within D. At one extreme end of the scale, C's ambassadors enjoy diplomatic immunity from D's legal jurisdiction. At the other end of the scale, $P$, as an ordinary national of $C$ is not a diplomat, and is subject to the legal jurisdiction of $D$. (The same is true today, as tourists are constantly reminded by their own governments when they travel abroad.) But in between the two ends of the scale, $\mathrm{C}$ asserts that $\mathrm{P}$ has some rights by virtue of the fact that he is a foreigner within D. Those rights boil down to C's claim that D cannot "deny justice" to $P$. International law, $C$ says, requires that $D$ observe some very minimal justice standards (Americans might call them "due process standards") toward P simply because $P$ is not a national of $D$. In C's view, $P$ enjoys a right when travelling in $D$ that the nationals of $D$ do not have, namely, the right under international law not to be the victim of a denial of justice at the hands of the government of $D$.

Despite C's advocacy on the diplomatic level, if P's case had been presented in any international court, the court would have held in favor of D. This holding is simply a consequence of our initial assumption: that P's is a "case of first impression" where the particular right being claimed was never previously given judicial vindication. In other words, under international law, $C$ would have no claim against $D$. There is no "state practice" that $\mathbf{C}$ can cite in favor of recognizing any rights of $\mathbf{P}$ within the territory of $D$. Of course, there is a great deal of "state practice" that D can cite, namely, the fact that in all prior cases, when a foreigner entered any territory, that foreigner was at the mercy of the territorial sovereign and international law had nothing to say about it.

Of critical importance here is that C's argument (that $P$ cannot be denied justice by $D$ by virtue of the fact that $P$ is a national of $C$ ) will make no impression on the court. The term "nationality" has no legal significance in this case of first impression. The court's opinion will point out that "nationality" is a relationship between $C$ and $P$, and therefore whether $P$ is a "national" of $C$ is entirely dependent upon the laws of $C$. (This remains true today.) The court will then go on to say that C's laws, including its "nationality" laws, can only have effect within the territorial jurisdiction of C. C's laws do not have extraterritorial effect. C's laws of "nationality" cannot be binding upon D. In short, "nationality" within C is a relationship that is predicated upon the laws of $\mathrm{C}$, and exhausts its power when the laws 
of $\mathrm{C}$ cease to apply. International law imposes no obligation on $\mathrm{D}$ to respect C's legislation concerning nationality.

The court might add that P's case is entirely different from that of C's ambassadors resident in D. When C's ambassadors entered D, they presented their credentials to the government of D. D's government accepted those credentials. Under well-established international legal norms of diplomatic immunity, the acceptance of those credentials meant that $D$ agreed to allow C's ambassadors diplomatic immunity within D, just as D's ambassadors, after presenting their credentials to $C$, enjoyed diplomatic immunity in $\mathrm{C}$.

If customary international law was unchangeable, if it retained the content it had in ancient Babylonia, then today Professor Henkin could not make the statement I have previously quoted several times: that "[u]nder customary international law, a state is obligated to treat foreign nationals in accordance with an international standard of justice. . .."65 That obligation simply did not exist in the early days of complete national sovereignty over any individuals within the national territory. Those prevailing rules of customary law certainly were not changed by statute, since no world legislature has ever existed that could change the rules of international law. So, something must have happened. Something must have effected a change in customary law. The only thing that could have changed was state practice. Since I have chosen the C-D case as a thought experiment describing the pivotal casethe case that inaugurated a change in the preexisting rule of international law reserving domestic jurisdiction over any person to the territorial sovereign-the C-D case must have unfolded in such a way as to change state practice.

The C-D case, as I have described it, did not come before a court. Although I discussed what a court might have held in that case-that the court would have awarded the decision to $\mathrm{D}$ on the basis of preexisting law-the case itself was not adjudicated in court. If it had been adjudicated in court, there would have been no change in the law, because international courts cannot change customary law; they must apply it as it is. Customary law only changes by virtue of a change in state practice. What international courts hold is not "state practice."

We will assume some further events in the C-D case. Since these events

${ }^{65}$ Henkin, supra note 2 , at 40 n.32.

${ }^{66}$ However, a national court deciding a case of international law is engaging in state practice. For an enumeration of reasons, see Doehring, supra note 8. 
must have occurred at some time or other, we are entitled to assume that they occurred whenever state practice changed. We proceed on the assumption that the C-D case is the one in which state practice changed.

Recall that in our hypothetical case P's relatives and friends back in C obtained the support of official of government $C$ to bring diplomatic pressure upon officials of government D. C's ambassadors might first argue that $D$ cannot deny justice to $P$ because $P$ is a "national" of $C$, but as we have seen, this argument is an empty formality. D can argue that "nationality" is a relationship dependent upon C's law only, and C's law does not extend to D's territory. Next, C's ambassadors argue that $C$ has a strong interest and concern in P's welfare, not just because $P$ is a "national" of $C$ in the legal sense, but also because the term "national" symbolized the web of ancestral and familial relationships that make $P$ "one of us" for whom we extend our support. $C$ might also add that $C$ is prepared, on a reciprocal basis, to extend to any nationals of $D$ who may visit $C$ the same right not to be "denied justice" at C's hands. On this reciprocity argument, D might counter that (1) it does not care about its own citizens and their welfare if they travel abroad, or (2) its own citizens do not do much travelling, because D is a beautiful, self-sufficient country and no one wants to travel to dingy C. (I mention this reciprocity argument, and how it might be countered, because "reciprocity" does not always account for the formation of customary rules of law, e.g., land-locked states have no reciprocal interest in granting to coastal states a wide territorial sea.)

$\mathrm{D}$ might reply that $\mathrm{P}$ loses his "nationality" rights when he voluntarily enters $D$, and that $C$ should not have any interest or concern in a person who leaves C's territory. However, this is only an argument, and as such cannot be conclusive upon $C$ because either $C$ has an interest and concern in P's welfare or $\mathrm{C}$ does not have that interest and concern. Nothing $\mathrm{D}$ says can change C's interest and concern because interest and concern are facts. C can demonstrate its interest and concern in P's welfare both by insisting on the diplomatic level that it has interest and concern in his welfare, and by indicating that it is willing to back up this interest and concern by appropriate countermeasures if $D$ does not immediately release $P$ from prison and either pay him a sum of money to recompense him for the maltreatment or at least assure $C$ that it will never again deny justice to any national of $C$.

Suppose the ambassadors of $\mathrm{C}$ and $\mathrm{D}$ have reached a stalemate; no further 
arguments work. ${ }^{67} \mathrm{C}$ decides to take a forceful step on behalf of its national P. C threatens to take a particular "countermeasure" (this is C's terminology, not D's at this point) unless $D$ releases $P$ from prison and pays $C$ a sum of money on P's behalf that C can use to compensate $P$ for P's injuries. ${ }^{68}$ Suppose $C$ threatens to seize a public vessel of $D$ 's that is presently docked in one of C's ports, to sell the vessel at auction, to deduct a substantial sum of money from the sale for the injury and incarceration of $P$, and to remit the balance of the proceeds of sale, if any, to $D$. Let us call this the "vessel initiative." D immediately replies that it would regard the vessel initiative by $C$ as an unjustified and provocative act of war.

The issue now is joined: whether the vessel initiative is a "countermeasure" or an "act of war." From D's point of view it is an act of war, one that is entirely unjustified, unjustified because D regards its maltreatment of $P$ as a matter within its sovereign jurisdiction for which it is accountable to no other state. $C$, on the other hand, regards D's maltreatment of $P$ as unjustified and giving rise to a legitimate claim for redress. Since C's request for redress was rejected by $\mathrm{D}, \mathrm{C}$ believes it has the right to engage in what I have elsewhere called a "reciprocal entitlement violation."69 C believes that it can take an entitlement of $D$, in this case, $D$ 's property right in its own vessel currently docking in one of C's ports, and violate that right as a proportionate punishment ("countermeasure") against D for D's maltreatment of P. It is a "tit-for-a-different-tat," in the terminology I've previously suggested, ${ }^{70}$ because $C$ has violated an entitlement of $D$ that is quite unrelated to D's delict. If, for example, $C$ had maltreated a national

${ }^{67}$ In other words, C's "diplomatic protest" has been to no avail. C must either give up and go home or escalate the matter by threatening to take forcible measures. A threat to take forcible measures is more than a protest; it is an act that could result in counter-threats escalating into war. Some writers think that a mere protest is enough to form customary law; I believe they are mistaken. See Anthony D'Amato, Protests, INT'L LAW ANTHOLOGY, supra note 8 , at 107-10.

${ }^{68}$ In classic international law, $P$ had no standing. P's injuries, if any, were reconceptualized as injuries to P's state C. See generally INT'L LAW ANTHOLOGY, supra note 8, at 31215 (excerpting EDWIN M. BORCHARD, THE DIPLOMATIC PROTECTION OF CTTIZENS ABROAD OR THE LAW OF INTERNATIONAL Clams (1915); HeRBert W. BRIGgS, THE LAW OF NATIONS (2d ed. 1952); ANTHONY D'AMATO, INTERNATIONAL LAW: PROCESS AND PROSPECT (1987) (adapted with modifications)).

${ }^{6}$ Anthony D'Amato, Is Intermational Law Really "Law"?: The "Reciprocal Entitlements Violation" Argument, INT'L LAW ANTHOLOGY, supra note 8, at 41-48.

${ }^{70}$ Anthony D'Amato, A Reformation of Customary Law: The Quantitative Element (Act, Abstention or Committment), INT'L LAW ANTHOLOGY, supra note 8, at 70-73. 
of $\mathrm{D}$, it would have been a "tit-for-tat" response."

So now we are down to brass tacks. Either C's vessel initiative is a countermeasure or it is an unjustified and provocative act of war. Which is it? Nothing in my statement of the C-D case can provide us an answer to this question because all I can do is set up the categories on behalf of $\mathbf{C}$ and D. But the answer is, in fact, known. What actually happened is that D gave in and accepted C's characterization of C's act as a countermeasure. Of course we don't know at what point in the C-D interaction that $D$ gave in. $\mathrm{D}$ might have conceded the entire matter when $\mathrm{C}$ made its threat to seize D's vessel, or D might have been stubborn and held out, and $C$ might have been forced to seize the vessel and sell it at auction and retain a portion of the proceeds. If $C$ had taken these actual steps, then the choice was D's whether to regard C's action as an act of war and forcibly retaliate or to simply accept the "punishment" and consider the matter settled.

How do we know for sure that $\mathrm{C}$ prevailed? We know it from the historical fact that there had to be a first case that changed the old rule in favor of $D$ (the rule of complete territorial sovereignty) to a new rule in favor of $C$ (the rule that C's nationals temporarily present in $D$ are entitled to a level of treatment by $D$ that does not fall below a standard that could be called "denial of justice"). Since there had to be a first case when the old rule changed, that first case is, by definition, our C-D case. ${ }^{72}$

${ }^{71}$ The "tit-for-tat" response, though apparently more just on its face, actually can be more unstable, spiraling downward until both nations end up in a war. See D'Amato, supra note 69, at 45-48.

72 Why did D give in when previous states in D's position did not? Over the course of years, or even of centuries, values change. In earlier times, states regarded people as expendable and worth very little. But human worth grew over time. At some point it was inevitable that a person's (P's) relatives and friends would make enough of a fuss over P's plight in a foreign country as to enlist the home country's support on behalf of P. We can't identify the first case when this happened, but we know that it did happen. The stability of the intemational system dictated the result in the C-D case. Prior to the C-D case, the stability of the international system was served by allowing territorial sovereigns complete freedom of action within their territory vis-a-vis foreign nationals. But this freedom of action at some point in time was perceived to cause a danger to the stability of the international system, a danger because human life had become more valuable and, consequently, worth going to war about. So, system stability dictated a new rule, that territorial sovereigns should be constrained by certain minimal standards regarding the treatment of foreign nationals.

Today, as more human-rights norms become part of international law, we can see that the international system continues to act to preserve stability. Certain acts by governments against their own citizens are seen to be outrageous and unwarranted. Other nations express 
The C-D case displays state practice that generated customary law. The state practice consisted of an interaction between $C$ and $D$. This interaction was not just on the verbal level of arguments by ambassadors of both countries. The interaction proceeded at least to the level of a threat of forcible action. A threat of forcible action is state practice, and the nation that receives the threat can engage in retaliatory action. The interaction between $C$ and $D$, on the other hand, might have extended to the conclusion of the countermeasure ( $\mathrm{C}$ might have seized and sold the vessel). But there is no doubt that a threat by one state to use force against the interests of another state (here, D's property interest in its vessel), and/or the carrying out of such a threat, is "state practice." When D gave up, a new rule of customary law was created, a rule to the effect that if another nation maltreats foreigners within its territory at least as badly as the way D treated $P$, their home states have a right to engage in proportionate reciprocal entitlement violations against that state. More simply stated, the rule of international law has now become the one summarized by Professor Henkin: "Under customary international law, a state is obligated to treat foreign nationals in accordance with an international standard of justice. . . ."73

How can Professor Henkin say that this early human-rights norm, the right of a person visiting a foreign country not to be denied justice by that foreign country, is "not based on state practice at all"? He can only say this because his Sovereignty Paradigm allows him to notice just D's actions within D! Professor Henkin "sees" D maltreating $P$ as a purely internal matter, just as today he "sees" acts of genocide, apartheid, and torture as purely internal acts of states. He concedes that these acts violate international norms, but his Sovereignty Paradigm disables him from explaining how the international norms arose.

What he cannot "see" is the entire dimension of interactive state practice regarding these norms. In the $C-D$ case, he focuses on what happens to $P$

interest and concern in the well-being of these foreigners (these "internationals"). If the acting government continues to act with impunity, international reprisals (economic sanctions and ultimately forcible intervention) are threatened.

${ }^{73}$ Henkin, supra note 2, at 40 n.32. By the time of the U.S.-Mexico Bilateral Claims Commission that investigated numerous "denial of justice" claims in the 1920 s, still decades before the human rights revolution, the customary law on the subject was so universally accepted and understood that the reports of the Commission are almost entirely devoted to a detailed account of the facts of each case, the "law" being uncontroversial. For an account of these cases, see Anthony D'Amato \& Kirsten Engel, State Responsibility for the Exportation of Nuclear Power Technology, 74 VA. L. REV. 1011, 1031 (1988). 
within D's territory, but cannot "see" the threat by C to engage in reciprocal entitlement violations and D's decision to back down in the face of the threat. Or, if the threat was carried out, Professor Henkin still would be unable to "see" what $C$ did (seizing the vessel) as related to D's act (maltreating P). In short, by focusing exclusively on P's plight in D's territory, Professor Henkin does not see the C-D interaction and thus does not see state practice.

He cannot see state practice because he is a prisoner of the Sovereignty Paradigm, which disables him from seeing that D's acts have engaged retaliatory countermeasures from other states. He is still rooted in the belief that what a nation does within its own territory is its own business, and thus $C$ 's threats to take countermeasures are viewed as extra-legal intrusions in the case. It is like the scientists described by Kuhn who interpret certain measurements as anomalies or errors rather than reconceptualizing their theories to account for these new measurements. The Sovereignty Paradigm disables its adherents from including within their legal vision the state practice I have described as the C-D interaction. They think what $\mathrm{C}$ does is irrelevant, and they think that D's reaction is irrelevant, because they believe that all the legally relevant action occurs within D's territory.

Thus, any human rights norm is viewed by adherents to the Sovereignty Paradigm as an inexplicable intrusion into territorial sovereignty. They don't know how or why these human norms arose (they give us vague and illusory "explanations" like "non-conventional" law, jus cogens, national constitutions, the Zeitgeist of the World, etc.), yet they are willing to acknowledge the norms when everybody else does. However, they continue to regard them with suspicion because they are "derogations" from territorial sovereignty, and they are slow to acknowledge any new ones.

A Neutral Paradigm that does not exclude relevant evidence would display a great deal of state practice accompanying the rise of human rights norms since 1945. The economic sanctions and boycotts against South Africa may have made the difference in South Africa's decision to dismantle apartheid and to move toward a multi-racial democracy. Economic sanctions today against Serbia constitute the response of nations outside Yugoslavia who have an interest and concern in the protection of the citizens in Bosnia against genocide and mass rape. I've argued that the military interventions by the United States in Grenada and Panama should be viewed as human rights interventions (although other people interpret those interventions 
differently). ${ }^{74}$ As I write these words, the United States is contemplating military intervention in Haiti, and spokespersons for the Clinton Administration are emphasizing human rights violations in Haiti above all other reasons for the possible intervention. ${ }^{75}$

These economic sanctions and military interventions, threatened and actual, are only the most prominent examples of scores of instances since 1945 of state action to lend support to persons against the human rights depredations of their own governments. All of these reactions by the international community constitute "reciprocal entitlement violations." They are inexplicable except as "countermeasures" to violations of the growing international law of human rights. The Sovereignty Paradigm is blind to the legal significance of all these economic sanctions and threatened (and imposed) military interventions. Professor Henkin does not view these countermeasures as constituting state practice; he says that the "nonconventional" law of human rights "is not based on ... state practice at all."76 On the contrary, they are the most manifest and important examples of state practice in the recent history of international law.

The importance of the threat of intervention with respect to the emerging human right to democratic governance, one that somehow failed to make Professor Henkin's list, ${ }^{77}$ is found in the Moscow Document, signed by thirty-seven states, which declares that the participating states:

74 See DEBATE: Resolved that the U.S. Intervention in Panama Violated International Law, in INT'L LAW ANTHOLOGY, supra note 8, at 208-25 (excerpting Ved P. Nanda, The Validity of United States Intervention in Panama Under International Law, 84 AM. J. INT'L L. 494 (1990); Tom J. Farer, Panama: Beyond the Charter Paradigm, 84 AM. J. INT'L L. 503 (1990); Anthony D'Amato, The Invasion of Panama Was a Lawful Response to Tyranny, 84 AM. J. INT'L L. 516 (1990); Sarah A. Rumage, Panama and the Myth of Humanitarian Intervention in U.S. Foreign Policy: Neither Legal Nor Moral, Neither Just Nor Right, 10 ARZ. J. INT'L \& COMP. L. 1 (1993); TESON, supra note 48.

75 The threat turned out to suffice; military intervention was not needed to restore the Aristide government.

${ }^{76}$ Henkin, supra note 2, at 38.

7 See Democracy, INT'L LAW ANTHOLOGY, supra note 8 at 367-80 (excerpting Thomas M. Franck, The Emerging Right to Democratic Governance, 86 AM. J. INT'L L. 46 (1992); Babacar Ndiaye, International Cooperation to Promote Democracy and Human Rights: Principles and Programmes, 49 INT'L COMMISSION JURISTS REV. 23 (1992) and including Anthony D'Amato, What Kind of Democrary Do We Want to Export?, INT'L LAW ANTHOLOGY, supra note 8 , at $373-80$ ). 
will support vigorously, in accordance with the Charter of the United Nations, in case of overthrow or attempted overthrow of a legitimately elected government of a participating State by undemocratic means, the legitimate organs of that State upholding human rights, democracy and the rule of law, recognizing their common commitment to countering any attempt to curb these basic values. ${ }^{78}$

If any student of international law as late as the 1930s had said that the form of government of a state is any foreign state's concern, that person would have been drummed out of the international law academy. But in the closing decade of the twentieth century, people have come to realize that a democratic government, while not a perfect form of government, may be the best internal safeguard of human rights. The Moscow Document makes this reasoning explicit. A norm of international law is emerging that prohibits a nation from overthrowing its own democratic government. The Moscow Document should drive the last few nails into the coffin of the Sovereignty Paradigm. Alas, the latter will live co-extensively with the lives of its adherents. It's easier to change the world than to change the world-view of some law professors. When Professor Henkin said that "law professors are a conservative lot,"79 he may not have appreciated how close to home, or how understated, his observation really was.

\section{Treaties as a Mode of State Practice}

Finally, we need to take up the question of the definition and content of the new human rights norms. If my argument so far is accepted, we have located the source of these norms in state practice. But the formation of customary norms in cases like the C-D interaction previously described will not yield the specificity we desire. To get this specificity, we, of course, cannot dispense with state interactions and state practice. What we need to do is to find evidence of that practice in another place. It is the most obvious place of all.

Consider the thought experiment just concluded in which I tried to show the dimension of state practice involved in a pivotal case in which a

${ }^{78}$ Moscow Document, supra note 45 , at 1677.
${ }^{9}$ Henkin, supra note 2 , at 43. 
customary rule changed content due to the interaction of the two affected states. It is clear that most rules of customary international law have not arisen this way. If they did, states would move to the brink of war whenever a customary rule of international law was perceived by one state to have outlived its usefulness. Fortunately, international law has long recognized a mechanism for change in the rules of customary international law that does not require brinkmanship. The mechanism is absurdly simple, and has been with us since time immemorial. Only another paradigm, the Contract Paradigm, has prevented a number of scholars from seeing it. ${ }^{80}$

The mechanism is the international agreement. In the C-D thought experiment discussed above, there would have been no need for $\mathbf{C}$ to threaten the deprivation of one of D's entitlements in order to protect its national. All $\mathrm{C}$ had to do was to secure D's agreement in advance of the incident. A treaty of Amity, Commerce, and Navigation between C and D could have provided that the parties guarantee to each other's nationals a minimum standard of treatment.

Many international law scholars, including most of those who studied law in the United Kingdom or the United States, carry around in their minds an almost impervious Contract Paradigm. It goes as follows. A treaty is simply a contract between states. Like any other contract, its provisions apply only to the parties. (There is a limited exception for extending contract provisions to third-party beneficiaries, but contract obligations cannot be so extended.) The contract creates a mini-regime of "law" just for the parties. The parties are free in their contract to derogate from the general law applicable to everyone or to reinforce that law if they so choose. ${ }^{81}$

${ }^{80}$ Some readers may think that all the attention I gave in this article to the Sovereignty Paradigm indicated that it was my main scholarly bête-noire. Far from it; it is only recently, in the context of thinking through the customary law of human rights, that I've come to see the distorting effect of the Sovereignty Paradigm. Instead, it is the Contract Paradigm that has played a central role in the work I have done on international law theory in the past quarter century. It is the first thing I grappled with as a student in Richard Baxter's seminar in international law during my law school days, the first thing I wrote about in a full-length article, and the centerpiece of my 1971 book on custom. But this is the first time that I have labelled it the "Contract Paradigm." The terminology is unimportant, the concept has been a preoccupation of my entire academic career.

${ }^{81}$ There is an exception here for contracts whose substantive provisions violate public policy, such as a contract to commit a murder or a contract for the delivery of prohibited substances. Under municipal contract law, such provisions are void and unenforceable. The international law analogue are treaties whose provisions violate jus cogens. The unsolved problem in international law is not that jus cogens is possible, but rather, how does it arise 
Armed with the Contract Paradigm, international law scholars conclude that the provisions in any treaty cannot affect the general customary law applicable to all states. They believe that a treaty, like a contract, can only create law for the parties. No amount of logical persuasion, no amount of empirical evidence, can dislodge this faith that treaties are just like contracts. I must admit that I sometimes feel like a few individuals must have felt prior to the sixteenth century when they said that evidence and logical deduction proved that the earth was round. By venturing to make such an assertion the teeth of the prevailing Flat Earth Paradigm, these individuals risked being imprisoned, drawn, and quartered.

No matter how much empirical evidence is adduced, paradigms like the Contract Paradigm and the Flat Earth Paradigm like invading armies trump the evidence of our senses and the logic of our intellects. Nearly everyone in Western Civilization for the five thousand years prior to 1500 (when Copernicus' astronomical observations were beginning to be published) believed that the earth was flat and motionless, that if you dug down into the earth you would reach solid rock and if you kept going you would reach Hell. They believed that boats that sailed beyond the horizon were in danger of falling off the earth and plunging into the everlasting abyss. They believed that the sun travelled across the sky during the day. Above the visible sky lurked the Kingdom of Heaven. ${ }^{82}$

How did all these people prior to Copernicus explain the ability of the sun, once it had set in the West, to get all the way around to the east again so that it could rise the next day? The sun could not circle around the earth because the earth was flat and below it was Hell. So, many people simply despaired of explaining the motion of the sun. Various religious explanations were proffered-gods transporting the sun across the heavens in a golden chariot. Others assumed that when the sun set in the west, its light went out. Then the sun could reverse its journey in the dark so that it could get back to the east by the next morning and light up again. However, no astronomer was able to find a dark disk moving across the sky during the night, so the sun must have been particularly clever at hiding its return trip. The most simple explanation-that the sun's apparent motion was simply how we saw it aboard a round earth that was revolving - was blasphemous.

Believers in the Flat Earth Paradigm were confronted with the evidnece of meteorites. They could observe in some places a huge crater, and in the

and how can it be modified? See supra, note 20.

${ }^{82}$ Governed, no doubt, by Someone with the world's greatest Sovereignty Paradigm. 
middle of it (if one dug a hole) an enormous sunken boulder. The simple explanation would have been that a rock fell from the sky and impacted the earth, causing the crater. But anyone who said this could be tortured at an Inquisition or burned at the stake, because it was uncontrovertible common sense that rocks are so heavy that they could not possibly have gotten from the earth into the sky in the first place. But there was a standard explanation that was consistent with the Paradigm: meteorites were rocks that bubbled up from Hell. Since the rocks from Hell were fire-hot, there was a huge splash when they surfaced. This splash is the crater.

I wish that scholars today could look at all the evidence and the logic that contradicts the Contract Paradigm. But paradigms are difficult to dislodge because they govern the way that we interpret the evidence and logic. No amount of empirical evidence regarding meteors would have convinced people five hundred years ago that rocks could go up into the air and fall back down. Even if some people had actually observed a meteor land on earth and told everyone what they had seen, they would have been disbelieved and regarded as suffering from a collective delusion. If I ask people to read Emmerich de Vattel's Law of Nations ${ }^{83}$ with an open mind and see where Vattel got his international law from, no one is willing to take me up. At least in science, other scientists are willing to read the result of empirical observations and experimentation. But in international law, it is hard to convince anyone to replicate an experiment or observe something that they are not predisposed to see.

Vattel and Blackstone wrote the two main treatises on law at the time of the American Revolution. The founding fathers had both volumes in their libraries. Blackstone's Commentaries were regarded as the authoritative source for domestic law, and Vattel's Law of Nations the authoritative source for international law. No single work on international law has even enjoyed an influence comparable to Vattel's. ${ }^{84}$ Vattel was a "positivist" in that he did not cite Scripture or "natural law" for the source or rules, the way that Grotius had done before him. In fact, Vattel did not use citations. The prevailing standards of scholarship in his day did not require revealing one's sources. This fact means that we have to expend some effort in tracing back to determine where Vattel's rules of customary law came from, an effort that

83 E. DE VATTEL, Le DROIT DES GENS; OU, PRINCIPES DE LA LOI NATURELLE APPLIQUES A LAW CONDUITE ET AUX AFFAIRS DES NATIONS ET DES SOUVERANS (1758).

${ }^{84}$ Lassa Oppenheim's Law of Nations may have had as important an influence on Japan's view of international law at the start of the twentieth century. 
requires the kind of time that most busy scholars of international law do not have.

I submit that Vattel used as his source of rules of customary international law the more than one thousand treaties that were available for his perusal. These treaties were mainly bilateral, although by Vattel's day there were some multilateral treaties involving a handful of countries (usually the result of a peace settlement). Vattel regarded these treaties as containing the "positive" rules of international law, i.e., the rules that states actually adopted. The treaties covered the same topics that Vattel covered in his treatise: state boundaries, diplomatic immunity, rights of aliens, belligerency and neutrality law, and the like. ${ }^{85}$ I have found upon examination that the rules contained in these treaties had the same content as the rules of customary international law expounded by Vattel. The conclusion is obvious: Vattel used the treaties as a source of general customary international law.

Although regarded as a "positivist," Vattel emphatically was not a prisoner of the Contract Paradigm. If he had been, then he could not have made generalizations from the treaties he studied. Rather, he would have had to say, for example, that the international law rule between England and France is one thing (deriving from their treaties of 1403 and 1521), the rule between France and Holland is slightly different (deriving from their bilateral treaty of 1675), and so forth. Instead, Vattel took the provisions from these and other treaties, and generalized from them. The treaties simply created, for Vattel, rules of customary international law that were binding on all states.

Nor was this conclusion idiosyncratic with Vattel. In the first place, Vattel's book was extraordinarily influential, its influence extending to the invocations of international law in the United States Constitution and in the organic legislation of the First Congress. Secondly, Vattel's "positivist" followers used the same methodology. They simply updated Vattel's views by consulting treaties that were entered into after the publication of Vattel's treatise. By the time of Oppenheim's First Edition at the start of the twentieth century, the Vattellian prescriptions were regarded as bedrock rules of international custom.

One could take the curious position-like the ancient's view of the sun sneaking back across the sky from west to east during the nighttime-that Vattel accepted only those treaty provisions that codified preexisting rules of

\footnotetext{
${ }^{85}$ It is interesting that with one transposition of letters, the word "treaties" becomes the word "treatise."
} 
international customary law. In my teacher Richard Baxter's phrase, a treaty can provide "evidence" of the underlying customary rule. ${ }^{86}$ But how can we tell whether a particular provision in a treaty is "evidence" of an existing customary rule or is in derogation of that rule? The only way we can tell is if we already know what the underlying rule of customary law is. If we know the content of the customary rule, then we can place it alongside the treaty and see if the treaty is consistent with it or derogates from it. But if our goal is determining what the rule of customary law is, why would we go to the trouble of determining whether a provision in a treaty is or is not consistent with the rule? So long as we already know what the customary rule is, we surely cannot care very much whether a particular treaty is or is not consistent with it. To say that a treaty rule that we find to be consistent with the underlying customary rule is "evidence" of that rule does not add to our information about the customary rule. It does not tell us, for example, why a treaty rule that is inconsistent with the underlying customary rule would not be evidence of a new and contrary rule of custom. Indeed, within the Contract Paradigm, the entire enterprise of looking into treaties for custom is otiose because treaty provisions can have no impact upon general customary law.

The more interesting question is the psychological one: why have so many scholars like Professor Baxter written about the relation of treaties to custom, only to conclude that treaties are like contracts and therefore have no necessary relation to custom? They have done so, I submit, because of a sense of uneasiness, of cognitive dissonance. They are good enough scholars to see the vast evidence all around them that provisions in treaties transmute into norms of customary law. What they cannot understand is the mechanism by which this transmutation takes place. And the reason they cannot see the mechanism is that they are captives of the Contract Paradigm.

If a scholar could possibly replace his or her Contract Paradigm with a Neutral Paradigm, the academic situation would improve markedly. One could then look at treaties unaccompanied by the baggage of domestic contract law. A treaty is after all an international instrument: there is no necessary reason why it should conform to the domestic law of contracts. ${ }^{87}$

${ }^{86}$ Richard Baxter, Multilateral Treaties as Evidence of Customary International Law, 41 BYIL 275 (1965-66).

87 Indeed, wholly apart from the thesis that provisions in treaties generate customary norms, there are numerous substantive differences between treaties and contracts. For a detailed study of these differences, see ANTHONY D'AMATO, INTERNATIONAL LAW 
One's eyes would then be opened to see the vast and virtually uncontradicted evidence throughout the history of international law of treaty provisions generating rules of customary international law binding upon all states. This is more true today than ever before, because all the human rights norms that are the subject of this Colloquium were generated by multilateral conventions.

What is the precise logical mechanism by which provisions in treaties become a source of international customary law? For this I refer the interested reader to my previous detailed work on this question, which would be too long (because it necessarily ties in with the mechanism of customary law generation in the absence of treaties) to try to summarize here. ${ }^{88}$

\section{CONCLUSION}

Professor Henkin is surely right that human rights norms have become part of customary international law binding on all states. But he has not given us a satisfactory explanation of the source of these norms. Calling them "non-conventional" only hides the problem. Yet it is fundamentally important to find a source for the norms; otherwise, they remain vague, inchoate, and arguable, and strike many people outside the international law profession as illusory.

Even within the profession, there are scholars like Professor Weisburd who believe that human rights norms do not exist apart from treaty provisions (that bind only the parties). Professor Weisburd's position flies in the face of the uncontrovertible conclusion reached by Professor Henkin and most other scholars that human rights norms are clearly a part of today's customary international law. Yet it is clear that Professor Weisburd's position reflects his unease with the question of sources. As a captive of the Contract Paradigm, Professor Weisburd is unable to see the vast evidence of

COURSEBOOK 80-98 (1994). Indeed, an argument the other way around can be made: that we really should have a Treaty Paradigm that explains treaties and to some extent explains contracts. See INT'L LAW AUTHOLOGY, supra note 8, at 86-89.

${ }_{88}$ Anthony D'Amato, Treaties as a Source of General Rules of International Law, 3 HARV. INT'L L.J. 1 (1962); D'AMATO, supra note 33, at 103-66; Anthony D'Amato, The Concept of Human Rights in International Law, 82 CoLUM. L. REV. 1110 (1982); Anthony D'Amato, An Alternative to the Law of the Sea Convention, 77 AM. J. INT'L L. 281 (1983); Anthony D'Amato, Custom and Treaty; A Response to Professor Weisburd, 21 VAND. J. TRANSNAT'L L. 459 (1988); INT'L LAW ANTHOLOGY, supra note 8, at 94-101; ANTHONY D'Amato, INTERNATIONAL LAW: PROCESS AND Prospect 146-203 (2d ed. 1995). 
treaties as a source of customary law.

I submit that the only logically satisfying and empirically validating position to take on the source of human rights norms is that they derive from provisions in treaties. But people who are prisoners of the Contract Paradigm are disabled from taking such a position. I can only hope that with the passage of time this Paradigm, like the Sovereignty Paradigm, will gently erode, and that a new generation of scholars will look back on these paradigms as archaic curiosities and wonder what all the fuss was about. 